\title{
Grazing exclosures solely are not the best methods for sustaining alpine grasslands
}

\author{
Xixi Yao ${ }^{1}$, Jianping Wu ${ }^{\text {Corresp., }}{ }^{1,2}{ }^{\text {, Xuyin Gong }}{ }^{2}$, Xia Lang ${ }^{2}$, Cailian Wang ${ }^{2}$ \\ ${ }^{1}$ College of Animal Science and Technology, Gansu Agricultural University, Lanzhou, People's Republic of China \\ 2 Gansu Academy of Agricultural Science, Lanzhou, People's Republic of China \\ Corresponding Author: Jianping Wu \\ Email address: 18993075304@163.com
}

\section{Background}

Grazing is widely regarded as a critical factor affecting the vegetation structure, productivity and nutritional value of natural grasslands. To protect and restore degraded grasslands, non-grazed exclosures is considered as a valuable tool. However, it is not clear whether long term non-grazed exclosures of grazers can improve the condition and nutritional values of vegetation and soil properties.

\section{Methods}

We have compared the impact of long term non-grazed and continuous grazed management strategy on vegetation structure, nutritional values and soil properties of alpine meadow of the Qinghai-Tibet Plateau by field investigation (11-13 years) and indoor analysis during 2015-2017.

\section{Results}

Our results showed that long-term non-grazed exclosures clearly increased the aboveground biomass and coverage of plant functional types. Long-term non-grazed exclosures improved the development of all vegetation types, except NG (GG, grass species type; SG, sedge species type; LG, leguminous species type; FG, forbs species type and NG, noxious species type). Long-term non-grazed exclosures significantly improved all six measured soil properties (TN, total nitrogen; TP, total phosphorus; TK, total potassium; AN, available nitrogen; AP, available phosphorus and AK, available potassium) in 0-10 cm soil layer, considerable effect on the improvement of all measured soil properties, except TK in $10-20 \mathrm{~cm}$ soil layer and all measured soil properties, except TN and TK in 20-30 cm soil layer were observed. However, long-term non-grazed exclosures significantly decreased biodiversity indicators i.e., Species richness, Shannon diversity index and Evenness index of vegetation. A substantial decrease in the density, biodiversity and nutritional values (CP (crude protein), IVTD (in vitro ture digestibility) and NDF (neutral detergent fiber)) of all vegetation types, except NG were recorded. While a downward trend in above ground biomass and all measured soil properties, except TP and TK were observed during 2015-2017 in alpine meadows due to long term grazed treatment. The density, diversity and nutritional value (CP and IVTD) of long-term non-grazed alpine meadows showed a downward trend over time (2015- 2017). By considering the biodiversity conservation and grassland livestock production, long-term non-grazed exclosures is not beneficial for the improvement of density, biodiversity and nutritional values of plant functional types. Thus, our study suggests that rotational non-grazed and grazed treatment would be a good management strategy to restore and improve the biodiversity and nutritional values of plant functional types in natural grassland ecosystem. 
1 Research paper

2 Title

3 Grazing exclosures solely are not the best methods for sustaining alpine grasslands

4 Running title: Long-term non-grazed exclosures decreases the density, biodiversity and 5 nutritional value

7 Xixi Yao ${ }^{1}$, Jianping $\mathrm{Wu}^{1,2}{ }^{*}$, Xuyin Gong${ }^{2}$, Xia Lang ${ }^{2}$, Cailian Wang ${ }^{2}$

8

91 College of Animal Science and Technology, Gansu Agricultural University, Lanzhou, People's 10 Republic of China

112 Gansu Academy of Agricultural Science, Lanzhou, People's Republic of China

12 Corresponding Author:

13 Jianping $\mathrm{Wu}$

14 No. 1 Agricultural Academy Village Anning, Lanzhou, Gansu, 730070, People's Republic of 15 China

16 Email address: wujp@gsagr.ac.cn 


\section{Abstract}

\section{Background}

Grazing is widely regarded as a critical factor affecting the vegetation structure, productivity and nutritional value of natural grasslands. To protect and restore degraded grasslands, non-grazed exclosures is considered as a valuable tool. However, it is not clear whether long term nongrazed exclosures of grazers can improve the condition and nutritional values of vegetation and soil properties.

\section{Methods}

We have compared the impact of long term non-grazed and continuous grazed management strategy on vegetation structure, nutritional values and soil properties of alpine meadow of the Qinghai-Tibet Plateau by field investigation (11-13 years) and indoor analysis during 2015-2017.

\section{Results}

Our results showed that long-term non-grazed exclosures clearly increased the aboveground biomass and coverage of plant functional types. Long-term non-grazed exclosures improved the development of all vegetation types, except NG (GG, grass species type; SG, sedge species type; LG, leguminous species type; FG, forbs species type and NG, noxious species type). Long-term non-grazed exclosures significantly improved all six measured soil properties (TN, total nitrogen; TP, total phosphorus; TK, total potassium; AN, available nitrogen; AP, available phosphorus and AK, available potassium) in $0-10 \mathrm{~cm}$ soil layer, considerable effect on the improvement of all measured soil properties, except TK in 10-20 cm soil layer and all measured soil properties, except TN and TK in 20-30 cm soil layer were observed. However, long-term non-grazed exclosures significantly decreased biodiversity indicators i.e., Species richness, Shannon diversity index and Evenness index of vegetation. A substantial decrease in the density, biodiversity and nutritional values (CP (crude protein), IVTD (in vitro ture digestibility) and 
41 NDF (neutral detergent fiber)) of all vegetation types, except NG were recorded. While a 42 downward trend in above ground biomass and all measured soil properties, except TP and TK 43 were observed during 2015-2017 in alpine meadows due to long term grazed treatment. The 44 density, diversity and nutritional value (CP and IVTD) of long-term non-grazed alpine meadows

\section{Introduction}

54 Grasslands occupy $40 \%$ of earth's land surface and play an important role in ecosystem functions showed a downward trend over time (2015-2017). By considering the biodiversity conservation and grassland livestock production, long-term non-grazed exclosures is not beneficial for the improvement of density, biodiversity and nutritional values of plant functional types. Thus, our study suggests that rotational non-grazed and grazed treatment would be a good management strategy to restore and improve the biodiversity and nutritional values of plant functional types in natural grassland ecosystem. and grassland animal husbandry (Kemp et al., 2013; Jing et al., 2014; Wesche et al., 2016; Török et al., 2016; Török P \& Dengler, 2018). China occupy 400 million hectares of grasslands, which account for $42 \%$ of the world's land area, out of which 240 million hectares are located in the Qinghai-Tibet Plateau (QTP), supporting 16 million people directly (Kemp et al., 2013). About $70 \%$ of China's population resides in rural areas and many of these people rely on grassland animal husbandry (Yang et al., 2012). Therefore, QTP is an important source for the survival and development of people in China and also a significant ecological barrier shaping genetic structure (Kemp et al., 2013). Alpine meadows cover almost 85\% area of the QTP and play an essential role in ecosystem function and grassland animal husbandry in china (Jiang et al., 2012; Wen et al., 2018). 
65

66

67

Alpine meadows have been gradually degrading and desertifying since 1980. Previous studies reported that $90 \%$ of alpine meadows in QTP are degraded and 35\% of this area is described as "black-soil-type alpine meadow" due to the severity of degradation (Dong et al., 2007; Li et al., 2017). Grassland degradation may be due to many reasons. However, increasing population pressure, livestock quantity and overgrazing are usually considered as the main reasons for grassland degradation (Kemp et al., 2013; Chen et al., 2014). Overgrazing may lead to significant changes in plant community composition and structure (Zhou et al., 2005). In addition, overgrazing leads to an increase in potential evapotranspiration and local global warming and further accelerates degradation of alpine meadows (Du et al., 2004). Degradation of grasslands due to overgrazing will start a vicious circle in which degraded grasslands will be degraded due to invasions of rodents (Kang et al., 2007).

In order to relieve the problem of grassland degradation in QTP, Chinese Government has initiated a project at local state and authorities in 2004 named "returning grazing to grassland project". As a management tool of this project, exclosures was extensively used to to protect and restore degraded grassland ecosystems all over the world in recent decades (Wu et al., 2009; Jing et al., 2014; Cheng et al., 2016). This strategy has been in consideration for more than a decade in degraded and overgrazed areas of QTP, revealing a question: is this strategy successful in restoring degraded alpine meadows?

The degradation of grasslands has attracted great attentions in recent years and stimulated a large number of studies on use of exclosures (Wu et al., 2009; Wei et al., 2012; Shi et al., 2013). Studies showed that exclosures increases aboveground biomass, coverage, species diversity and soil nutrient content (Jiao et al., 2011; Shi et al., 2013; Li et al., 2017; Wen et al., 2018) but it decreases species density, richness and biodiversity by diminishing the dominant competitor species present during grazing (Mayer et al., 2009; Shi et al., 2013). Exclosures also increased the nutritional value of forage (Schönbach et al., 2012; Ren et al., 2016), which in turn affected the livestock production and performance (Mysterud et al., 2001, 2011). However, exclosures can lead to wastage of natural resources in livestock production (Cuevas et al., 2005). Thus, 
92

93

94

specific research should be done for the proper management of ecosystems and the achievement of protection objectives. In QTP, much research has been done to explore the effects of exclosures on alpine meadow ecosystem, vegetation structure, vegetation succession and soil characteristics under different degradation gradient, grazing intensities and grazing regime (Pettit et al., 1995; Gibson et al., 2000; Li et al., 2017; Wen et al., 2018). However, less work has been done to study the effects of exclosures on the nutritional values of plant functional types. In fact, nutritional values of vegetation are also of great importance for animal production along with ecosystem functions and services (Wen et al., 2018; Shang et al., 2013).

Livestock industry in QTP accounts for a significant proportion of government income (Kang et al., 2007). Livestock production is usually restricted by herbage nutritional yield, which depends on aboveground net primary productivity (ANPP) and herbage nutritional values (Ren et al., 2016). Forage with high nutritional values is characterized by high concentration of crude protein (CP), in vitro true digestibility (IVTD) and low concentration of neutral detergent fiber (NDF). At present, most areas of the grassland are in some state of degradation and the ANPP of grassland has decreased (Li et al., 2017; Wen et al., 2018). Meanwhile, the number of livestock in QTP region is still increasing, causing more overgrazing, resulting more grassland degradation and reduced ANPP of grassland (Yang et al., 2012). In addition, climatic factors also influence the grassland, such as extremely low temperature diminishes grass growth from October to May and due to low herbage mass animal productivity is severely limited (Yang et al., 2012). So, the importance of forage nutritional values in the production of livestock is highly recognized. Little work has been done focusing the effects of grassland degradation on vegetation characteristics, vegetation nutritional values and soil properties, especially the characteristics of plant functional types and the nutritional values of plant functional types as a whole has not yet been reported. The effects of long-term non-grazed and grazed management strategy on vegetation characteristics, vegetation nutritional values and soil properties in grassland are unclear.

In order to better understand the restoration and management of degraded grassland in QTP, it is necessary to study the vegetation characteristics, nutritional values and soil properties of 
119 alpine meadows as a whole. We hypothesized that aboveground biomass, coverage, density, 120 biodiversity, nutritional values of vegetation and soil properties will be improved in the absence

121 of grazed due to the absence of disturbance from herbivorous livestock. Thus, in this study, we 122 compared characteristics of plant functional types, functional types nutritional values and soil 123 properties during long-term non-grazed and grazed alpine meadows of QTP in order to evaluate 124 whether long-term non-grazed exclosures can improve the condition and nutritional values of 125 plant functional types and soil properties. The assessment of long-term non-grazed exclosures as management strategy will assist in preventing negative impacts on ecosystem and full utilization of grasslands resources.

128

129

130

131

132

\section{Materials and methods}

\section{Study site}

The study area was located on the Sanding Village in the northeastern edge of the Qinghai-Tibet Plateau, Kangle Town, Sunan County, Zhangye City of Gansu Province, in China (9948'E, $38^{\circ} 45^{\prime} \mathrm{N}$, and $3200 \mathrm{~m}$ above sea level). The annual average precipitation was $255 \mathrm{~mm}$ (19852017), with $\sim 85 \%$ occurring during the growing season (May-September) (Fig. 1b). The average annual temperature was approximately $3.8^{\circ} \mathrm{C}$ (1985-2017) (Fig. 1a). The annual cumulative temperature $\left(\geq 0^{\circ} \mathrm{C}\right)$ was approximately $2323.9^{\circ} \mathrm{C}(1985-2017)$ (Fig. 1c). The vegetation growth period was from June to September i.e., approximately 4 months. The type of grassland belonged to alpine meadow. The species richness was high, with $12-24$ species per $\mathrm{m}^{2}$ in this vegetation meadow. The vegetation was divided into five classes that included (gramineous grasses (GG); sedge grasses (SG); leguminous grasses (LG); forbs grasses (FG) and noxious species (NG)). The dominant species included: Kobresia humilis, Polygonum viviparum, Potentilla fruticosa and Caragana sinica (Yang et al., 2012) (Species are showed in Table 1). The soil of the alpine meadow belonged to meadow soil with high calcium content (Kemp \& Michalk, 2011).

\section{Experimental design}


144 The study area, including all research sites, was slightly degraded because it was used as summer 145 pasture and mainly grazed from June to September by Gansu Alpine Fine-wool sheep before 146 2005. Two treatments i.e., non-grazed and grazed treatments were started in $20^{\text {th }}$ June, 2005 147 under the same conditions, while sample collection was started from 2015. In each treatment 148 three sites, each site occupied 4 ha area (approximately $100 \mathrm{~m}$ away from each other, to insure an 149 unification of experiment conditions, all sites had similar slope gradient, aspect, elevation and 150 soil type (Cheng et al., 2016; Li et al., 2017; Wen et al., 2018)), were randomly selected over a 151 homogeneous area (total 24 ha area). At each site, using the line transects method, three $100 \mathrm{~m} \times$ $152100 \mathrm{~m}$ monitoring blocks (almost at a distance of $50 \mathrm{~m}$ ) with the same conditions were selected, 153 altogether eighteen sample blocks for two treatments were chosen. The non-grazed sites had 154 been excluded from livestock grazing for 10 years. The grazed sites, were fenced for the whole

155 156

157 year, was freely grazed from $20^{\text {th }}$ June to $20^{\text {th }}$ August with a 4.5 livestock units/ha (Gansu Alpine Fine-wool sheep, 18-month-old female sheep, average $35 \mathrm{~kg}$ live weight) during the grazing period. The grazing experiment started on $20^{\text {th }}$ June, 2005. Animal welfare and experimental procedures were carried out in accordance with the Guide for the Care and Use of Laboratory Animals, Ministry of Science and Technology of China and were approved by College of Animal Science and Technology of Gansu Agricultural University. Every effort was made to minimize animal pain, suffering and distress and to reduce the number of animals used. Gansu Alpine Fine-wool sheep management followed traditional practice, in which grazing sheep were kept in the grazing sites day and night with freely available drinking water. The paddock was owned by a local farmer, who agreed to its use for this experimental study. There were no endangered or protected species within the paddock.

\section{Aboveground vegetation community survey, plant and soil sampling}

Successive samples were collected on mid-August of 2015, 2016 and 2017 when aboveground biomass at the peak of biomass production. In every experimental block, 5 random sampling of quadrats $(1 \mathrm{~m} \times 1 \mathrm{~m})$ were done, having distance between each quadrat over $1 \mathrm{~m}$ from edge to edge to eliminate the effect of margin. Species composition, life type, edibility, coverage, 
171 aboveground biomass and density were recorded in each quadrat and each plant species was 172 clipped to 1-cm stubble height. Additionally, the plant functional types were divided into five 173 classes that included GG (grass species type), SG (sedge species type), LG (leguminous species 174 type), FG (forbs species type) and NG (noxious species type) (Wu et al., 2009; Zhang et al., 175 2018). Edible plants species mean those plants that can be eaten by animals while noxious 176 species mean noxious plants. Noxious species means plant species that are classified as 177 undesirable, noxious, exotic, injurious, or poisonous, pursuant to local government law, which 178 are of foreign origin, and can directly or indirectly injure crops, other useful plants, livestock, or 179 poultry (Parker et al., 1949). Dry matter in each functional group under the constant weight of 180 every quadrat drying at $70^{\circ} \mathrm{C}$ for 48 hours was determined. A total of 270 quadrants were 181 recorded during 3 years of experiment for long-term non-grazed and grazed treatments. Total 182 coverage, aboveground biomass (dry matter) and species density of alpine meadow plant 183 functional types were recorded. The information of all species is shown in Table 1. Species 184 abundance was calculated by using the number of species in each square. Species richness $(S)$, 185 Shannon diversity index $(H)$ and Evenness index $(E)$ of the vegetation was calculated using the 186 formula:

187 Species richness $(R): R=S$

188 Shannon diversity index $(H): H=-\sum_{i=1}^{s}(P i l n P i)$

189 Evenness index $(E): E=\frac{H}{\ln S}$

Where $S, H, P_{i}$ represents total species of alpine meadow vegetation community, Shannon diversity index and density proportion of i species, respectively (Shannon, 1948).

Along with this, surface soil was also removed from five spots of each quadrat. The center and four diagonal corners of each sampling quadrat were selected using the earth boring auger in 3 soil layers: $0-10,10-20$ and $20-30 \mathrm{~cm}$. Soil samples from five spots of each quadrat were 
195 196

197

198

199

200

201

202

203

204

205

206

207

208

209

210

211

212

213

214

215

216

217

218

219

220

mixed together to use as one soil sample. There were 270 soil samples in total from same soil layer for long-term non-grazed and grazed treatments during 3 years of experiments.

\section{Nutrients chemical analysis}

Nutritional values of four edible functional types were evaluated. Plant samples were dried, crushed and passed through $1 \mathrm{~mm}$ mesh screening by using Foss Tecator Cyclotec 1093 sample mill. The plant nutrition parameters included crude protein (CP), neutral detergent fiber (NDF) and in vitro ture digestibility (IVTD). Plant nitrogen (N) concentration was measured using Foss fully automated Kheltec 8400 (Feldsine et al., 2002) and utilized to calculated crude protein (CP) by using formula: $\% \mathrm{CP}=\% \mathrm{~N} \times 6.25$. NDF was analyzed using an ANKOM 2000 Fiber Analyzer on the basis of the two-stage method (Tilley \& Terry, 1963) while In vitro true digestibility (IVTD) was determined using an Ankom F57 filter bag (Goering \& Van, 1970; Van et al., 1991).

Soil samples were passed through $0.14 \mathrm{~mm}$ mesh screening after air-drying. The measurement of soil samples according to methods (Miller \& Keeney, 1982). Total nitrogen (TN) was obtained by the semi-micro Kjeldahl method. Total phosphorus (TP) and total potassium (TK) were determined with an inductive coupled plasma (ICP) emission spectrometer after digestion of the samples in concentrated $\mathrm{HNO}_{3}$. Available nitrogen (AN) was determined using the continuous alkali-hydrolyzed reduction diffusion method. Available phosphorus (AP) was extracted with sodium bicarbonate and determined by Olsen method. Available potassium (AK) was determined by $\mathrm{H}_{2} \mathrm{SO}_{4}-\mathrm{HCLO}_{4}$ digestion and the molybdenum antimony-ascorbic acid colorimetric method.

\section{Data analysis}

Mixed Model option in SPSS version 19.0 (IBM Corp., Armonk, New York, USA) based on an autoregressive covariance structure through ANOVA analyzing data was used. There were 270 observations [2 treatments $\times 9$ blocks $\times 5$ quadrants $\times 3$ years] for each functional type variables (Coverage, Plant density, Aboveground biomass, CP, IVTD and NDF) and soil property 
221 variables in each soil depth (Total N, Total P, Total K, Available N, Available P and Available

222 K). Repeated measurement analysis for each functional type variables and soil property variable

223 in every soil depth were performed using a mixed-effects model, including grazing treatment

224 (non-grazed, grazed), and blocks were selected to study the fixed effects with year (2015, 2016,

225 2017) as a repeated effect and their interactions. The ANOVA analysis was followed by least

226 significant difference (LSD) tests $(P<0.05)$.

\section{Results}

228

229

230

231

232

233

234

235

236

237

238

239

240

241

242

243

244

245

246

\section{Vegetation characteristics response to non-grazed treatment and year variations}

The vegetation coverage and aboveground biomass of non-grazed treatment were significantly higher than grazed treatment (Fig. 2; Table 2). The vegetation density, Species richness $(R)$, Shannon diversity index $(S)$ and evenness index $(E)$ of non-grazed treatment were considerably lower than grazed treatment (Fig. 2; Table 2). The sampling year notably influenced the vegetation coverage and density (Fig. 2; Table 2). The effect of non-grazed treatment on the coverage and density were highly influenced by sampling year (Fig. 3; Table 2).

In comparison to grazed treatment, non-grazed treatment considerably increased the coverage of all five vegetation types (Fig. 3; Table 2). Significant increase in the aboveground biomass of GG, SG was observed during non-grazed alpine meadows. Non-grazed treatment also increased the density of all five vegetation types (Fig. 3; Table 2). The sampling year only increased the coverage of LG and NG. The sampling year also increased the density of all vegetation types, except FG. However, Significant effect of interaction between non-grazed treatment and sampling year on the aboveground biomass of SG, LG and FG was observed (Fig. 3; Table 2).

Non-grazed treatment showed a significant decreasing trends over a period of time on the density of all five vegetation types (Fig. 4; Table 2) displaying minimum inclination in 2017 (Fig. 4; Table 2). In case of grazed treatment, the density of all five vegetation types first decreased and then showed an upward trend during the experimental period (Fig. 4; Table 2) with 
247 minimum reading during 2016 (Fig. 4; Table 2). The non-grazed treatment displayed first 248 decreasing and then an upward trend in the aboveground biomass of all five vegetation types 249 (Fig. 4; Table 2) with minimum value occurring during 2016 (Fig. 4; Table 2).

250

251

252

253

254

255

256

257

258

259

260

261

262

263

264

265

266

267

268

269

270

271

272

\section{Vegetation nutritional values response to non-grazed treatment and year variations}

In comparison to grazed treatment, non-grazed treatment significantly decreased the $\mathrm{CP}$ content of all vegetation types, except NG (Fig. 5; Table 3), it also decreased the IVTD of all vegetation types, except NG (Fig. 5; Table 3). Considerable decrease in the NDF content of all vegetation types, except NG (Fig. 5; Table 3) during non-grazed treatment was also recorded. The sampling year showed positive effect on the CP content of GG and SG (Fig. 5; Table 3). The significant increase in the IVTD of GG and LG were recorded during non-grazed treatment (Fig. 5; Table 3). The NDF content of GG and SG increased were observed during the sampling year (Fig. 5; Table 3). The relation of non-grazed treatment and sampling year showed significant effect on the CP content of all vegetation types, except NG (Fig. 5; Table 3). While in case of IVTD, only SG showed significant effect (Fig. 5; Table 3). The NDF contents of SG and LG were observed effected during the study of interaction of non-grazed treatment and sampling year (Fig. 5; Table 3) were seen.

The CP and IVTD contents of all vegetation types, except NG in non-grazed alpine meadows showed a gradually decreasing trend (Fig. 6; Table 3) while in case of grazed alpine meadows, the CP and IVTD contents of all vegetation types, except NG firstly showed decreasing trend and then an upward trend was observed during the experiment period (Fig. 6; Table 3) both showing lowest value during 2016 year (Fig. 6; Table 3). However, the NDF content of all vegetation types, except NG showed an increasing trend in non-grazed alpine meadow during experiment, displaying highest value during year 2017 (Fig. 6; Table 3). In case of grazed alpine meadows, the NDF content of all vegetation types, except NG first increased and then a downward trend was recorded (Fig. 6; Table 3), the highest value was observed in year 2016 (Fig. 6; Table 3). 
273

274

275

276

277

278

279

280

281

282

283

284

285

286

287

288

289

290

291

292

293

294

295

296

297

\section{Soil properties response to non-grazed treatment and year variations}

As compared to grazed treatment, non-grazed treatment significantly increased all six measured soil properties in the $0-10 \mathrm{~cm}$ soil layer while an increase in all measured soil properties, except TP were recorded in the $10-20 \mathrm{~cm}$ soil layer. In $20-30 \mathrm{~cm}$ soil layer all measured soil properties, except TN and TK considerably increased (Fig. 7; Table 4). Sampling year also effected the soil properties such as significant increase in the soil TK, AN and AK in the 0-10 $\mathrm{cm}$ soil layer was observed and an increase in the soil AN and AK in the 10-20 cm soil layer (Fig. 7; Table 4) was also recorded. The interaction of non-grazed treatment and sampling year significantly affected the soil TN, TP, AN and AK in the $0-10 \mathrm{~cm}$ soil layer. A significant effect on all measured soil properties, except TK in the 10-20 cm soil layer and on all measured soil properties, except TP and TP in the 20-30 cm soil layer were observed (Fig. 7; Table 4).

In non-grazed alpine meadows, the all measured soil properties, except TK of three soil layers i.e., 0-10, 10-20 and 20-30 $\mathrm{cm}$ showed a gradually increasing trend during the whole experimental period, the lowest value occurred in 2017 year (Fig. 8; Table 4). While in case of grazed alpine meadows, the TP, TK and AP of three soil layers $(0-10,10-20$ and 20-30 cm) first decreased and then an upward trend was recorded during the whole experimental period with the lowest value displayed in 2016 (Fig. 8; Table 4). Overall TN, AN and AK of three soil layers (0$10,10-20$ and $20-30 \mathrm{~cm}$ ) showed a gradually decreasing trend during the whole experimental period, and displayed the lowest value in 2017 year (Fig. 8; Table 4).

\section{Discussion}

\section{Vegetation characteristics response to non-grazed treatment and year variations}

The restoration of degraded grassland ecosystem is a complex and long-term ecological process (Cheng et al., 2016; Török and Helm, 2017; Török et al., 2018). Non-grazed treatment is generally regarded as a useful tool to restore the productivity of degraded grasslands ecosystem (Spooner et al., 2002). Many studies have shown that the restoration of grassland by non-grazed 
298 grasslands can be assessed by biomass, coverage, density and diversity of vegetation (Wilkins et 299 al., 2003; Cheng et al., 2016). In our research, we selected aboveground biomass, coverage, 300 density, biodiversity and richness to assess the impact of non-grazed treatment on vegetation. 301 Research has shown that climatic factors are also the main driving force of degradation, greater

302

303

304

305

306

307

308

309

310

311

312

313

314

315

316

317

318

319

320

321

322

323

324

than overgrazing for alpine grassland (Niu et al., 2008). The variation of vegetation biomass between years is primarily influenced by local rainfall, temperature and sunshine radiation (Akiyama \& Kawanura, 2007; Niu et al., 2008; Wu et al., 2009; Miao et al., 2015; Ren et al., 2016). In our study area, the annual average temperature and $\geq 0^{\circ} \mathrm{C}$ accumulative temperature gradually increased, while annual rainfall decreased (Fig. 1). That indicates that there was a warmer and dry trend in the local climate, which might be a very influential factor in the succession of plant communities (Bai et al., 2004).

Our study showed that long-term non-grazed exclosures remarkably increased the aboveground biomass and coverage of vegetation, but decreased the density and biodiversity of vegetation (Fig. 2; Table 1, 2). Similar results have also been reported in other grassland types (Haugland et al., 1999; Wu et al., 2009; Wang et al., 2012). Non-grazed exclosures increased the coverage and aboveground biomass of gramineous (GG) and sedge (SG) plants in alpine meadow communities by excluding intake of herbivores, which had good palatability for domestic animals (Fig. 3, 4; Table 1,2). Studies have shown that forage with good palatability is more competitive than those forage with poor palatability, and non-grazed exclosures significantly increased the biomass of gramineous and sedge species which have good palatability (Gallego et al., 2004; Wu et al., 2009). These results are consistent with previous reports (Gallego et al., 2004; Wu et al., 2009; Shang et al., 2013), supporting that non-grazed exclosures benefits for the improvement of biomass and coverage of four plant functional types (GG, SG, LG and FG) and inhibition in the development of noxious species type (NG). Livestock grazing accelerated the loss of plant roots and leaf biomass, promoted the recycling of nutrients (Semmartin et al., 2008), and decreased the vegetation biomass of grazed alpine meadows. However, non-grazed exclosures showed a negative effect on the density and 
325 biodiversity of plant functional types. In high biomass grasslands, the loss of vegetation diversity 326 might be due to greater competition of canopy resources (i.e. light and air) (Huston, 1994). Some 327 of the less competitive species had limited availability of light or nutrient (Grime, 1998; Van et al., 2004), resulted in their decrease density or species disappearance. On the contrary, grazed treatment decreased the biomass of dominant functional types (GG and SG) (Table 1), allowing other functional types in the community to have more development opportunities and promoting balanced development of the community.

The alpine meadows 11-13 years non-grazed exclosures reflected changes in functional types from smaller to larger, and in density from higher to lower (Table 1). In non-grazed alpine meadows, the biodiversity of five plant functional types (GG, SG, LG, FG and NG) decreased (Table 1). The density changes of five plant functional types (GG, SG, LG, FG and NG) in the non-grazed area means that the number of species in the non-grazed alpine meadow was less, total aboveground biomass was higher and number of newly appeared species is fewer (Fig. 2, 3; Table 1). This indicated that the non-grazed exclosures has affected the concealment of the habitat and led to the loss of species diversity. The concealment of the habitat determines the supplement of local plant seedlings (Oba et al., 2001) and disruption of some unusual plant species (Inderjit, 2005). The species density and diversity in the fenced alpine meadow is significantly higher than grazing alpine meadow. Grazed treatment inhibits the development of dominant community (GG and SG), increases spatial heterogeneity, and makes other functional types (LG, FG and NG) in the community to grow to achieve a balanced development (Fig. 3, 4), which is consistent with the previous reports (Begon et al., 1990; Sheppard et al., 2002; Schippers and Joenje, 2002; Holdo et al., 2007; Wu et al., 2009).

Grazed treatment is regarded as a key factor leading to grassland degradation; meanwhile it is also a main driving force for grassland succession (Holdo et al., 2007). Plant diversity is mainly dependent on grazing intensity. Overgrazing may lead to the grassland degradation and biodiversity loss and light grazing may lead to grassland succession to woodland and the loss of grassland habitats. Not only grazed intensity is important, but also the time of grazing and the 
352 type of grazed livestock are also important (Hulme et al., 1999). It is necessary to do more 353 research about the effects of non-grazed and grazed on alpine meadows, especially in terms of 354 global climate change (AR \& SJ, 2001).

355

356

357

358

359

360

361

362

363

364

365

366

367

368

369

370

371

372

373

374

375

376

377

\section{Vegetation nutritional values response to non-grazed treatment and year variations}

It has been reported that grazing usually increased the forage nutritional value (Bai et al., 2012; Schönbach et al., 2012), which will in turn affects the performance of livestock (Mysterud et al., 2001, 2011; Lin et al., 2011; Müller et al., 2014). Our research showed that grazed treatment significantly increased the nutritional value (CP and IVTD) of four edible functional types (GG, SG, LG and FG), which is consistent with other studies (Schönbach et al., 2009; Fanselow et al., 2011; Ren et al., 2016). Firstly, a large amount of nitrogen was stored in the stems and leaves, because grazed forage had a higher relative absorbance of nitrogen and it was moved into the young tissue of shoots and leaves when herbage was taken (Lambers et al., 2009; Fanselow et al., 2011). Secondly, nitrogen originating from the dung and urine of grazed livestock had a positive effect on nitrogen concentrations of forage and herbivore excretions usually accelerated the rate of mineralization of the soil surface by senescent plant litter. As the soil mineral nitrogen increased, the nitrogen content in plants also increased (Semmartin et al., 2008; Wang et al., 2009; Jiang et al., 2012; Miao et al., 2015). Finally, grazed could affect the nutritional value of plants by using young and protein-rich parts and regenerating it, instead of aged parts of plants (Mysterud et al., 2001; Schönbach et al., 2009; Ren et al., 2016). Due to the regeneration of new tissues under grazing pressure, the maturation and lignification of the species are delayed, and the CP content increased, our findings support these results (Milchunas et al., 1995; Garcia et al., 2003).

The CP and IVTD of four edible functional types (GG, SG, LG and FG) showed a gradually decreasing trend with the increase of non-grazed time, while NDF gradually increased. The CP and IVTD of functional types in grazed alpine meadows showed a decreasing trend at first and then increasing trend with time was observed. Contrary to the changing trend of CP and IVTD, 
378

379

380

381

382

383

384

385

386

387

388

389

390

391

392

393

394

395

396

397

398

399

400

401

402

403

404

NDF content showed at first rising trend and then decreasing trend. This might be due to rainfall in the study area. As reported previously that variation in precipitation rate between years affects the herbage nutritional values (Miao et al., 2015). The herbage nutritional value depends on the amount of precipitation, which increases with increasing rainfall, consistent with past research (Schönbach et al., 2009; Müller et al., 2014; Miao et al., 2015). Our results also indicated that nutritional value of four edible functional types in relatively wet years (2015 and 2017) was higher than in dry year (2016) (Fig. 1). Plant growth was limited by the amount of precipitation and water availability (Miao et al., 2015). In relatively wet years, abundant precipitation accelerated soil water utilization rate and soil mineralization, and promoted the ability of plants to absorb nitrogen $(\mathrm{N})$, thus promoting biomass production (Austin et al., 2004; Xu \& Zhou, 2005). Meanwhile, drought can caused severe water stress, resulted in rapid ripening of plants, thereby reducing the concentration of $\mathrm{N}$ in forage. Therefore, water stress in drought years increases forage fibrosis and reduces forages digestibility, while in wet years due to high rainfall maturation process delays, forage fibrosis reduces and in turn forage digestibility was improved. However, in case of non-grazed alpine meadow, the CP and IVTD of four edible functional types (GG, SG, LG, and FG) did not show any increasing trend with increase in rainfall. This may be due to the fact that as the non-grazed time was increased, biomass accumulated with the passage of every year. Mature and aged tissues inhibited the germination and growth of young tissues from the seedlings in the growing season, causing the CP and IVTD to decrease and NDF to increase every year.

Livestock grazing can significantly change the structure and nutritional value of vegetation and their trampling behavior and excrement can also affect the community structure and soil properties of the ground (Gibson et al., 2000). Therefore, vegetation succession, functional types characteristics and nutritional values are closely related to livestock grazed. For the succession of grasslands vegetation and utilization of grassland resources, regular grazed and non-grazed treatment are beneficial to grasslands management.

\section{Soil properties response to non-grazed treatment and year variations}


405 As the non-grazed time increased, the soil TN, TP, AN, AP and AK significantly went up, 406 showing that the soil nutrients of degraded alpine meadow were being restored by fencing 407 approach (Jing et al., 2014), indicating that natural succession of degraded soils in alpine 408 meadow areas of the QTP could improve soil fertility. The improvement of soil properties in 409 alpine meadows with increased of non-grazed time had two explanations: first, the productivity 410 of vegetation has a direct impact on the accumulation of litter. With the accumulation of litter 411 and in the presence of soil moisture, litter decomposition rate enhanced and soil nutrients showed 412 an increasing trend (Wu et al., 2009). Secondly, higher soil nutrients might be due to higher 413 community coverage. Previous studies have found that vegetation coverage has an obvious 414 impact on the quality of soil nutrients (Zhang et al., 2011), our results further supports these 415 findings.

416 The interaction of soil and plant is a complex process (Lambers et al., 2009). The movement 417 of energy and nutrients in soil can directly and indirectly reflect the species composition, 418 productivity and nutritional value of vegetation (Venterink, 2011). In non-grazed grasslands, 419 firstly, the plant community of non-grazed grassland locked-in nutrients (Harris et al., 2007) in 420 their tissues, reduced the outflow of energy and nutrients from soil-plant system to the consumer 421 (grazed livestock), especially gramineous (GG) and sedge (SG) functional types had high 422 productivity and good quality (Moretto \& Distel, 1997). Vegetation resources (coverage and 423 productivity) were significantly improved with the increase in non-grazed time. These resources 424 could go back to the soil by the decomposition of the litter layer (Bardgett \& Wardle, 2003; Wu 425 et al., 2009). Secondly, non-grazed removed the trampling effect of grazing livestock, improved 426 soil characteristics, increased water interception and improved vegetation status (Li et al., 2007). 427 Along with the development of aboveground vegetation, the better vegetation conditions reduced 428 the wind erosion and some nutrients richer particles and dust was captured in the soil (Liu et al., 429 2007). Thirdly, the improvement of soil nutrients had a positive regeneration effect on the 430 aboveground biomass and structure of plant functional types, because the utilization of higher 431 nutrient levels is beneficial for the competition of gramineous (GG) and sedge (SG) functional 
432 types to other species (Van et al., 2004). Finally, decrease in the quantity of rodents (Myospalax 433 fontanierii and Microtus leucurus) has a positive effect on soil biological communities and soil 434 processes by altering the input of soil resources (Bardgett \& Wardle, 2003). However, for grazed 435 grasslands, some energy and nutrients flow from soil-plant system to livestock by grazing, which 436 at first altered soil properties, reduced the litter and root biomass that were fed back into the soil 437 after decomposition (Gao et al., 2008); Secondly, the edible functional types grazed by livestock 438 had higher litter decomposition rate and efficient soil nitrogen than inedible functional group 439 forage (Moretto \& Distel, 2002). Finally, long-term trampling by livestock transforms soil composition, infiltration rates, bulk density, soil porosity, limiting soil respiration and reducing soil microbial activity (Holt, 1997).

Therefore, soil nutrient has a positive effect on the aboveground biomass, composition and nutritional value of plant functional types. However, this study only analyzed the soil chemical characteristic. In future, the relationship between plant functional types and soil physics or biology should also be considered.

\section{Conclusions}

447 The restoration of degraded grassland ecosystem is a complex long-term ecological process 448 (Lambers et al., 2009). 11-13 years of non-grazed exclosures in QTP have led to subsequent changes of plant functional type biomass, structure, nutritional values, quantity and quality of

450 litter inputs to the soil. Long-term non-grazed exclosures has increased aboveground biomass and coverage of plant functional types. It is beneficial for the improvement of four edible functional types (GG, SG; LG and FG), but inhibited the development of NG type. Long-term non-grazed exclosures also significantly improved $0-30 \mathrm{~cm}$ soil TN, TP, TK, AN, AP and AK.

454 However, it decreased the species biodiversity indicators, including the Species richness, the 455 Shannon diversity index and Evenness index of vegetation. It also decreased the density, 456 biodiversity and nutritional values of four edible plant functional types (GG, SG, LG and FG). 457 There exist a dilemma between biodiversity protection and grazed utilization in grasslands under 
458 heavy grazing pressure and long-term non-grazed exclosures. As disturbance measures, non459 grazed and grazed treatment had opposite impacts on aboveground biomass, coverage, density, 460 biodiversity, nutritional values and soil properties. However, it is from highest to moderate levels 461 of disturbance for species density and diversity, according to the "intermediate disturbance 462 hypothesis" (Connell \& Slatyer, 1977). Landsberg reported that moderate grazing pressure 463 increases the diversity of vegetation at local natural biotope (Landsberg et al., 2002). Our 464 research indicated that non-grazed exclosures can be used as a useful restoration tool 465 implemented at large scales in many regions to restore aboveground biomass and coverage of 466 degraded grassland. Meanwhile, grazed treatment could be used as an effective grasslands 467 management strategy to increase biodiversity and nutritional values of plant functional types in 468 long-term fenced grasslands. We recommend that long-term non-grazed grasslands should 469 reasonably utilize non-grazed and grazed treatment for grassland management. We suggest that 470 rotational grazed and non-grazed treatment can be regarded as a beneficial management strategy 471 for grasslands management around the world where common problems exist. More meaningful 472 studies should be carried out in the future for the restoration, management and utilization of 473 grassland, such as fertilization, fencing time, grazing intensity, grazing time and grazed livestock 474 species.

\section{Acknowledgements}

We acknowledge the herdsmen and Sunan County Meteorological Bureau for their assistance and for providing long-term meteorological data.

\section{References}

AR W., SJ O. 2001. Grasslands, grazing and biodiversity: editors' introduction. Journal of applied ecology 38:233237.

Austin, A. T., Yahdjian, L., Stark, J. M., Belnap, J., Porporato, A., Norton, U., Schaeffer, S. M. 2004. Water pulses and biogeochemical cycles in arid and semiarid ecosystems. Oecologia 141:221-235.

Akiyama, T., Kawamura, K. 2007. Grassland degradation in China: methods of monitoring, management and restoration. Grassland science 53:1-17. 
485

486

487

488

489

490

491

492

493

494

495

496

497

498

499

500

501

502

503

504

505

506

507

508

509

510

511

512

513

514

515

516

517

518

519

520

Begon M., Harper JL., Townsend CR. 1990. Ecology: individuals, populations and communities. Blackwell Scientific Publications, Oxford.

Bardgett R D., Wardle D A. 2003. Herbivore-mediated linkages between aboveground and belowground communities. Ecology 84:2258-2268.

Bai, Y., Han, X., Wu, J., Chen, Z., Li, L. 2004. Ecosystem stability and compensatory effects in the Inner Mongolia grassland. Nature 431:181-184.

Bai, Y., Wu, J., Clark, C. M., Pan, Q., Zhang, L., Chen, S., Han, X. 2012. Grazing alters ecosystem functioning and C: N: P stoichiometry of grasslands along a regional precipitation gradient. Journal of Applied Ecology 49:1204-1215.

Connell, J. H., Slatyer, R. O. 1977. Mechanisms of succession in natural communities and their role in community stability and organization. The American Naturalist 111:1119-1144.

Cheng, J., Jing, G., Wei, L., Jing, Z. 2016. Long-term grazing exclusion effects on vegetation characteristics, soil properties and bacterial communities in the semi-arid grasslands of China. Ecological Engineering 97:170178.

Du M, Kawashima S, Yonemura S, Zhang X, Chen S. 2004. Mutual influence between human activities and climate change in the Tibetan Plateau during recent years. Global and Planetary Change 41:241-249.

Dong, S. K., Gao, H. W., Xu, G. C., Hou, X. Y., Long, R. J., Kang, M. Y., Lassoie, J. P. 2007. Farmer and professional attitude to the large-scale ban on livestock grazing of grasslands in China. Environmental Conservation 34:246-254.

Feldsine, P., Abeyta, C., Andrews, W. H. 2002. AOAC International methods committee guidelines for validation of qualitative and quantitative food microbiological official methods of analysis. Journal of $A O A C$ International 85:1187-1200.

Fanselow, N., Schönbach, P., Gong, X. Y., Lin, S., Taube, F., Loges, R., Dittert, K. 2011. Short-term regrowth responses of four steppe grassland species to grazing intensity, water and nitrogen in Inner Mongolia. Plant and Soil 40:279-289.

Goering, H.K., Van Soest, P.J. 1970. Forage Fiber Analysis (apparatus, reagents and some applications). US Department of Agriculture Handbook, No. 379 ARS-USDA, Washington, DC.

Grime J P. 1998. Benefits of plant diversity to ecosystems: immediate, filter and founder effects. Journal of Ecology 86:902-910.

Gibson, R., Hewitt, A., Sparling, G., Bosch, O. 2000. Vegetation change and soil quality in central Otago Tussock grasslands, New Zealand. The Rangeland Journal 22:190-204.

Garcia, F., Carrere, P., Soussana, J. F., Baumont, R. 2003. The ability of sheep at different stocking rates to maintain the quality and quantity of their diet during the grazing season. The Journal of Agricultural Science 140:113-124.

Gallego, L., Distel, R. A., Camina, R., Rodríguez Iglesias, R. M. 2004. Soil phytoliths as evidence for species replacement in grazed rangelands of central Argentina. Ecography 27:725-732. 
521 Gao, Y. Z., Giese, M., Lin, S., Sattelmacher, B., Zhao, Y., Brueck, H. 2008. Belowground net primary productivity and biomass allocation of a grassland in Inner Mongolia is affected by grazing intensity. Plant and Soil 307:41-50.

Huston MA. 1994. Biological diversity, the coexistence of species on changing landscapes. Cambridge University Press, New York.

Holt J A. 1997. Grazing pressure and soil carbon, microbial biomass and enzyme activities in semi-arid northeastern Australia. Applied Soil Ecology 5:143-149.

Haugland E., Froud-Williams R J. 1999. Improving grasslands: the influence of soil moisture and nitrogen fertilization on the establishment of seedlings. Journal of Applied Ecology 36:263-270.

Hulme, P. D., Pakeman, R. J., Torvell, L., Fisher, J. M., Gordon, I. J. 1999. The effects of controlled sheep grazing on the dynamics of upland Agrostis-Festuca grassland. Journal of Applied Ecology 36:886-900.

Harris, W. N., Moretto, A. S., Distel, R. A., Boutton, T. W., Boo, R. M. 2007. Fire and grazing in grasslands of the Argentine Caldenal: effects on plant and soil carbon and nitrogen. acta oecologica 32:207-214.

Holdo, R. M., Holt, R. D., Coughenour, M. B., Ritchie, M. E. 2007. Plant productivity and soil nitrogen as a function of grazing, migration and fire in an African savanna. Journal of Ecology 95:115-128.

Inderjit. 2005. Plant invasions: habitat invasibility and dominance of invasive plant species. Plant and Soil 277:1-5.

Jiao, F., Wen, Z.M., An, S.S. 2011. Changes in soil properties across a chronosequence of vegetation restoration on the Loess Plateau of China. Catena 86:110-116.

Jiang, Y., Tang, S., Wang, C., Zhou, P., Tenuta, M., Han, G., Huang, D. 2012. Contribution of urine and dung patches from grazing sheep to methane and carbon dioxide fluxes in an Inner Mongolian desert grassland. Asian-Australasian journal of animal sciences. 25:207-212.

Jing, Z., Cheng, J., Su, J., Bai, Y., Jin, J. 2014. Changes in plant community composition and soil properties under 3-decade grazing exclusion in semiarid grassland. Ecological Engineering 64:171-178.

Kang L, Han X, Zhang Z, Sun OJ. 2007. Grassland ecosystems in China: review of current knowledge and research advancement. Proceedings of the Royal Society B: Biological Sciences 362:997-1008

Kemp D.R., Michalk D.L. 2011. Development of sustainable livestock systems on grasslands in north-western China. ACIAR Proceedings No. 134. Australian Centre for International Agricultural Research: Canberra. 189 pp.

Kemp, D. R., Guodong, H., Xiangyang, H., Michalk, D. L., Fujiang, H., Jianping, W., Yingjun, Z. 2013. Innovative grassland management systems for environmental and livelihood benefits. Proceedings of the National Academy of Sciences 110:8369-8374.

Landsberg, J., James, C. D., Maconochie, J., Nicholls, A. O., Stol, J., Tynan, R. 2002. Scale-related effects of grazing on native plant communities in an arid rangeland region of South Australia. Journal of Applied Ecology 39:427-444.

Li, X. R., Kong, D. S., Tan, H. J., Wang, X. P. 2007. Changes in soil and vegetation following stabilisation of dunes in the southeastern fringe of the Tengger Desert, China. Plant and Soil 300:221-231. 
557

558

559

560

561

562

563

564

565

566

567

568

569

570

571

572

573

574

575

576

577

578

579

580

581

582

583

584

585

586

587

588

589

590

591

Liu, B., Wu, N., Luo, P., Tao, Y. P. 2007. Characteristics of soil nutrient distribution in high-altitude meadow ecosystems with different management and degradation scenarios. Chinese Journal of Eco-Agriculture 15:45-48.

Lambers, H., Mougel, C., Jaillard, B., Hinsinger, P. 2009. Plant-microbe-soil interactions in the rhizosphere: an evolutionary perspective. Plant and Soil 321:83-115.

Lin, L., Dickhoefer, U., Müller, K., Susenbeth, A. 2011. Grazing behavior of sheep at different stocking rates in the Inner Mongolian steppe, China. Applied Animal Behaviour Science 129:36-42.

Li, W., Cao, W., Wang, J., Li, X., Xu, C., Shi, S. 2017. Effects of grazing regime on vegetation structure, productivity, soil quality, carbon and nitrogen storage of alpine meadow on the Qinghai-Tibetan Plateau. Ecological Engineering 98:123-133.

Moretto A S., Distel R A. 1997. Competitive interactions between palatable and unpalatable grasses native to a temperate semi-arid grassland of Argentina. Plant Ecology 130:155-161.

Miller RH., Keeney DR (eds). 1982. Methods of soil analysis. Part 2: chemical and microbiological properties, 2nd edn. American Society of Agronomy, Soil Science Society of America, Madison.

Milchunas, D. G., Varnamkhasti, A. S., Lauenroth, W. K., Goetz, H. 1995. Forage quality in relation to longterm grazing history, current-year defoliation, and water resource. Oecologia 101:366-374.

Mysterud, A., Langvatn, R., Yoccoz, N. G., Chr, N. 2001. Plant phenology, migration and geographical variation in body weight of a large herbivore: the effect of a variable topography. Journal of Animal Ecology 70:915923.

Moretto A S., Distel R A. 2002. Soil nitrogen availability under grasses of different palatability in a temperate semi-arid rangeland of central Argentina. Austral Ecology 27:09-514.

Mayer R, Kaufmann R, Vorhauser K, Erschbamer B. 2009. Effects of grazing exclusion on species composition in high-altitude grasslands of the Central Alps. Basic and Applied Ecology 10:447-455.

Mysterud, A., Hessen, D. O., Mobæk, R., Martinsen, V., Mulder, J., Austrheim, G. 2011. Plant quality, seasonality and sheep grazing in an alpine ecosystem. Basic and Applied Ecology 12:195-206.

Müller, K., Dickhoefer, U., Lin, L., Glindemann, T., Wang, C., Schönbach, P., Taube, F. 2014. Impact of grazing intensity on herbage quality, feed intake and live weight gain of sheep grazing on the steppe of Inner Mongolia. The Journal of Agricultural Science 152:153-165.

Miao, F., Guo, Z., Xue, R., Wang, X., Shen, Y. 2015. Effects of Grazing and Precipitation on Herbage Biomass, Herbage Nutritive Value, and Yak Performance in an Alpine Meadow on the Qinghai-Tibetan Plateau. PloS one 10:e127275.

Niu S W., Ma L B., Zeng M M. 2008. Effect of overgrazing on grassland desertification in Maqu County. Acta Ecologica Sinica 28:145-153.

Oba G., Vetaas O R., Stenseth N C. 2001. Relationships between biomass and plant species richness in arid-zone grazing lands. Journal of Applied Ecology 38:836-845. 
592

593

594

595

596

597

598

599

600

601

602

603

604

605

606

607

608

609

610

611

612

613

614

615

616

617

618

619

620

621

622

623

624

625

626

Parker, K. W. 1949. Control of noxious range plants in a range management program. Journal of Range Management 2:128-132.

Pettit N E., Froend R H., Ladd P G. 1995. Grazing in remnant woodland vegetation: changes in species composition and life form groups. Journal of Vegetation Science 6:121-130.

Ren, H., Han, G., Lan, Z., Wan, H., Schönbach, P., Gierus, M., Taube, F. 2016. Grazing effects on herbage nutritive values depend on precipitation and growing season in Inner Mongolian grassland. Journal of Plant Ecology 9:712-723.

Shannon C E. 1948. A mathematical theory of communication. Bell system technical journal 27:379-423.

Spooner P., Lunt I., Robinson W. 2002. Is fencing enough? The short-term effects of stock exclusion in remnant grassy woodlands in southern NSW. Ecological Management \& Restoration 3:117-126.

Schippers P., Joenje W. 2002. Modelling the effect of fertiliser, mowing, disturbance and width on the biodiversity of plant communities of field boundaries. Agriculture, ecosystems \& environment 93:351-365.

Sheppard, A. W., Hodge, P., Paynter, Q., Rees, M. 2002. Factors affecting invasion and persistence of broom Cytisus scoparius in Australia. Journal of Applied Ecology 39:721-734.

Semmartin M., Garibaldi L A., Chaneton E J. 2008. Grazing history effects on above-and below-ground litter decomposition and nutrient cycling in two co-occurring grasses. Plant and Soil 303:177-189.

Schönbach, P., Wan, H., Schiborra, A., Gierus, M., Bai, Y., Müller, K., Taube, F. 2009. Short-term management and stocking rate effects of grazing sheep on herbage quality and productivity of Inner Mongolia steppe. Crop and Pasture Science 60:963-974.

Schönbach, P., Wan, H., Gierus, M., Loges, R., Müller, K., Lin, L., Taube, F. 2012. Effects of grazing and precipitation on herbage production, herbage nutritive value and performance of sheep in continental steppe. Grass and Forage Science 67:535-545.

Shang, Z.H., B. Deng., L.M. Ding., G.H. Ren., G.S. Xin., Z.Y. Liu., Y.L. Wang., R.J. Long. 2013. The effects of three years of fencing enclosure on soil seed banks and the relationship with above-ground vegetation of degraded alpine grasslands of the Tibetan plateau. Plant and Soil 364:229-244.

Shi, X. M., Li, X. G., Li, C. T., Zhao, Y., Shang, Z. H., Ma, Q. 2013. Grazing exclusion decreases soil organic C storage at an alpine grassland of the Qinghai-Tibetan Plateau. Ecological Engineering 57:183-187.

Tilley, J. M. A., Terry, R. A. 1963. A two-stage technique for the in vitro digestion of forage crops. Grass and forage science 18:104-111.

Török P., Wesche K., Ambarli D., Kamp J., Dengler, J. 2016. Step(pe) up! Raising the profile of the Palaearctic natural grasslands. Biodiversity \& Conservation 25:2187-2195.

Török P., Helm A. 2017. Ecological theory provides strong support for habitat restoration. Biological Conservation 206:85-91.

Török P., Helm A., Kiehl K., Buisson E., Valkó O. 2018. Beyond the species pool: modification of species dispersal, establishment, and assembly by habitat restoration. Restoration Ecology 26:S65-S72. 
Török P., Dengler J. 2018. Palaearctic grasslands in transition: overarching patterns and future prospects. In: Squires, V.R., Dengler, J., Feng, H., Hua, L. (eds.) Grasslands of the world: diversity, management and conservation. CRC Press, Boca Raton, US. Ch. 2. pp. 15-26.

Van Soest P., Robertson J., Lewis B. 1991. Methods for dietary fiber, neutral detergent fiber, and nonstarch polysaccharides in relation to animal nutrition. Journal of dairy science 74:3583-97.

Van Der Wal, R., Bardgett, R. D., Harrison, K. A., Stien, A. 2004. Vertebrate herbivores and ecosystem control: cascading effects of faeces on tundra ecosystems. Ecography 27:242-252.

Venterink H O. 2011. Does phosphorus limitation promote species-rich plant communities? Plant and soil 345:1-9.

Wilkins, S., Keith, D., Adam, P. 2003. Measuring success: evaluating the restoration of a grassy eucalypt woodland on the Cumberland Plain, Sydney, Australia. Restoration Ecology 11:489-503.

Wu, G. L., Du, G. Z., Liu, Z. H., Thirgood, S. 2009. Effect of fencing and grazing on a Kobresia-dominated meadow in the Qinghai-Tibetan Plateau. Plant and Soil 319:115-126.

Wang, C. J., Tas, B. M., Glindemann, T., Rave, G., Schmidt, L., Weißbach, F., Susenbeth, A. 2009. Fecal crude protein content as an estimate for the digestibility of forage in grazing sheep. Animal Feed Science and Technology 149:199-208.

Wei D, Xu R, Wang Y, Wang Y, Liu Y, Yao T. 2012. Responses of CO2, CH4 and N2O fluxes to livestock exclosure in an alpine steppe on the Tibetan Plateau, China. Plant and Soil 359:45-55.

Wang, X.H., Yu, J.B., Zhou, D., Dong, H.F., Li, Y.Z., Lin, Q.X., Guan, B., Wang, Y.L. 2012. Vegetative ecological characteristics of restored reed (Phragmites australis) wetlands in the Yellow River Delta, China. Environmental management 49:325-333.

Wesche K., Ambarli D., Kamp J., Török P., Treiber J., Dengler J. 2016. The Palaearctic steppe biome: a new synthesis. Biodiversity \& Conservation 25:2197-2231.

Wen, L., Jinlan, W., Xiaojiao, Z., Shangli, S., Wenxia, C. 2018. Effect of degradation and rebuilding of artificial grasslands on soil respiration and carbon and nitrogen pools on an alpine meadow of the Qinghai-Tibetan Plateau. Ecological Engineering 111:134-142.

Xu, Z. Z., Zhou, G. S. 2005. Effects of water stress on photosynthesis and nitrogen metabolism in vegetative and reproductive shoots of Leymus chinensis. Photosynthetica 43:29-35.

Yang, B., Wu, J. P., Yang, L., Kemp, D., Gong, X. Y., Takahashi, T., Feng, M. T. 2012. Metabolic energy balance an countermeasures study in the north grassland of China. Acta Prataculturae Sinica 21:187-195.

Zhou H, Zhao X, Tang Y, Gu S, Zhou L. 2005. Alpine grassland degradation and its control in the source region of the Yangtze and Yellow Rivers, China. Grassland Science 51:191-203.

Zhang, C., Xue, S., Liu, G. B., Song, Z. L. 2011. A comparison of soil qualities of different revegetation types in the Loess Plateau, China. Plant and Soil 347:163-178.

Zhang, W., Ren, C., Deng, J., Zhao, F., Yang, G., Han, X., Tong, X., Feng, Y. 2018. Plant functional composition and species diversity affect soil $\mathrm{C}, \mathrm{N}$, and $\mathrm{P}$ during secondary succession of abandoned farmland on the Loess Plateau. Ecological engineering 122:91-99. 


\section{Figure 1}

Changes in annual average temperature $\left({ }^{\circ} \mathrm{C}\right)(\mathrm{a})$, annual average precipitation $(\mathrm{mm})(\mathrm{b})$ and cumulative temperature $\left(\geq 0^{\circ} \mathrm{C}\right)$ (c) in the region of this study. 

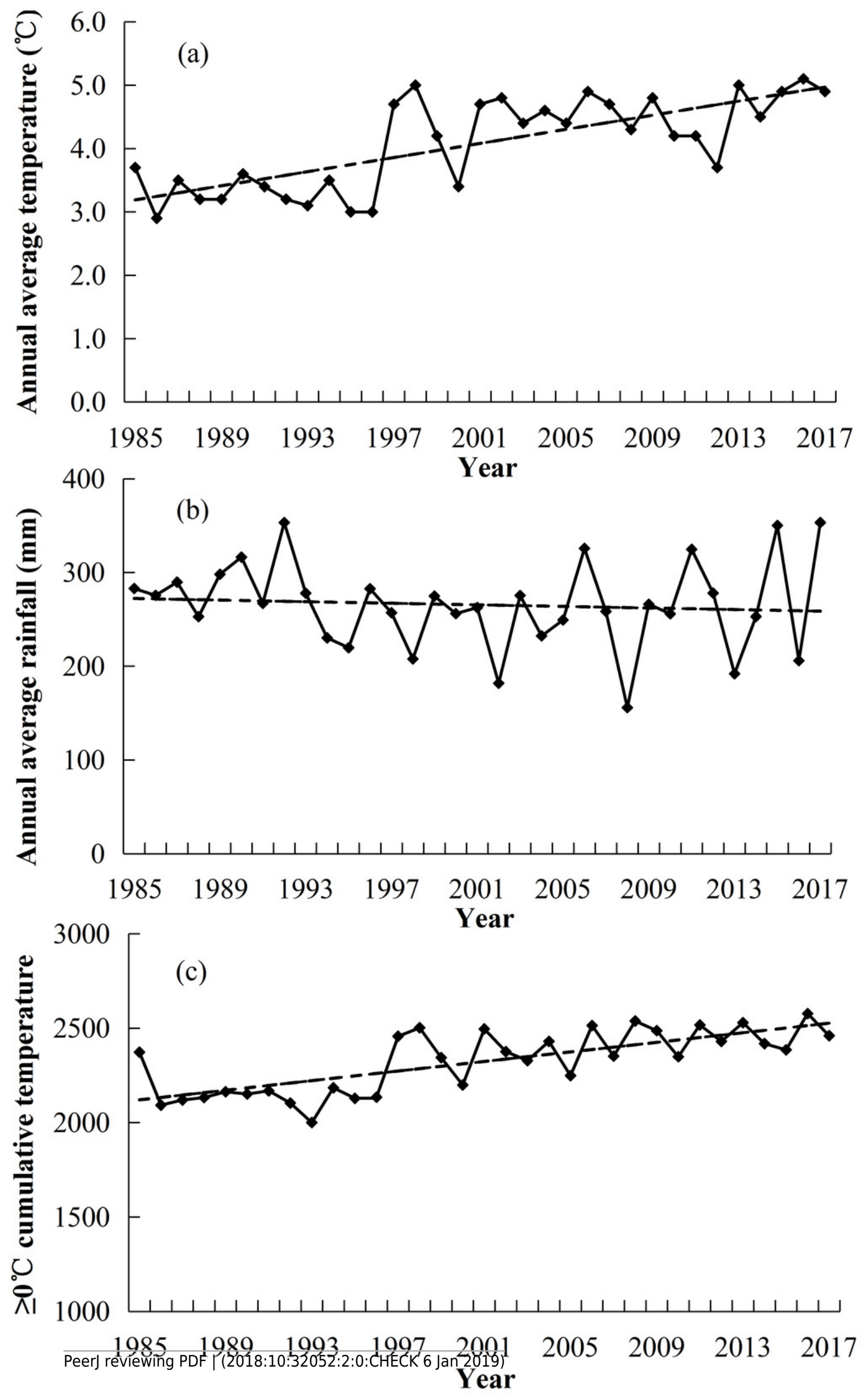


\section{Figure 2}

Effect of long-term non-grazed and grazed on vegetation Coverage (a), Aboveground biomass (b), Density (c), Richness index (d), Shannon diversity index (e) and Evenness index (f) of alpine meadows.

The values (Mean \pm SE) are means of 3 years (2015, 2016 and 2017); The symbols represent signigicant difference between non-grazed and grazed alpine meadow treatemnts, ${ }^{*} * *<<0.001,{ }^{* *} P<0.01, * P<0.05 ;$ ns, no significant difference. 

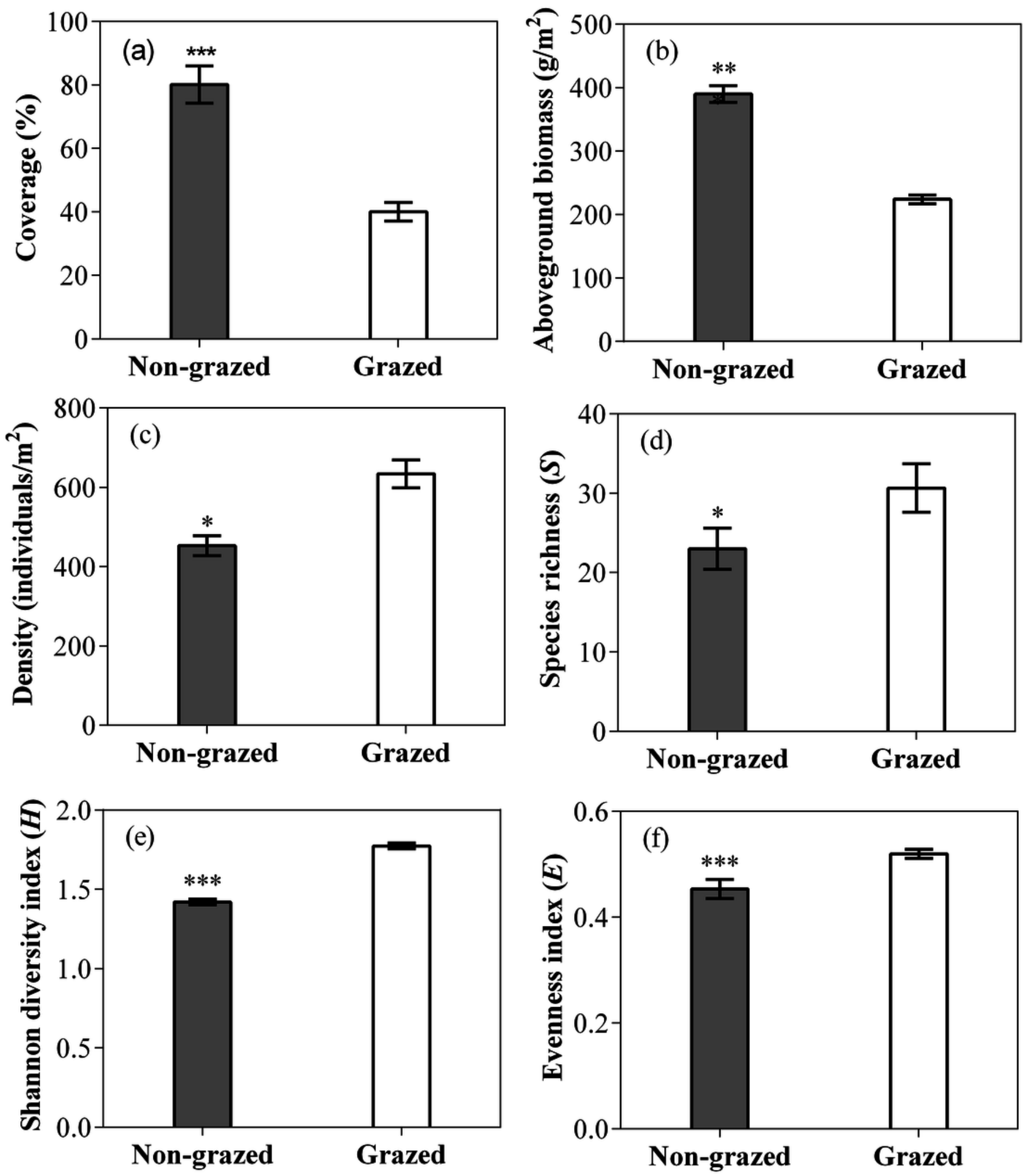


\section{Figure 3}

Effect of non-grazed and grazed on the Coverage (a, \%), Aboveground biomass ( $b$, $\mathrm{g} / \mathrm{m}^{2}$ ), Density $\left(\mathrm{c}\right.$, individuals $/ \mathrm{m}^{2}$ ) of five functional types of alpine meadows between non-grazed and grazed treatment.

The values (Mean \pm SE) are means of 3 years (2015, 2016 and 2017); For five functional types, GG, SG, LG, FG and NG represents grass species type, sedge species type, leguminous species type, forbs species type and noxious species type respectly. The symbols represent signigicant difference between non-grazed and grazed alpine meadow treatemnts, ${ }^{* * *} P<0.001, * * P<0.01, * P<0.05$; ns, no significant difference. 

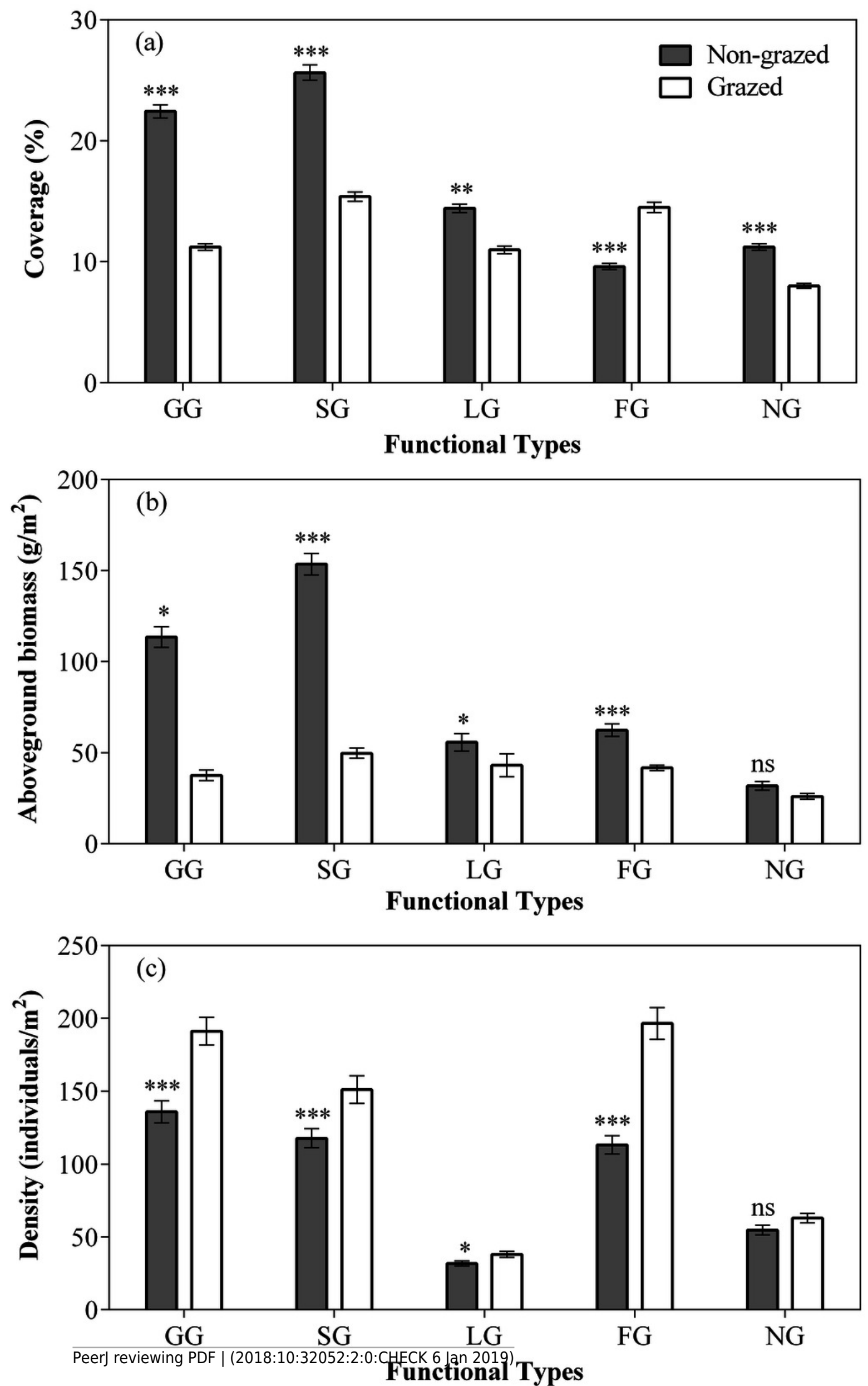


\section{Figure 4}

Changes of Coverage $(a, \%)$, Aboveground biomass $\left(b, g / m^{2}\right)$, Density (c, individuals $/ \mathrm{m}^{2}$ ) for total vegetation and five functional types between non-grazed and grazed alpine meadows.

The values (Mean \pm SE) are means of 3 years (2015, 2016 and 2017); For five functional

types, GG, SG, LG, FG and NG represents grass species type, sedge species type, leguminous species type, forbs species type and noxious species type respectly. 


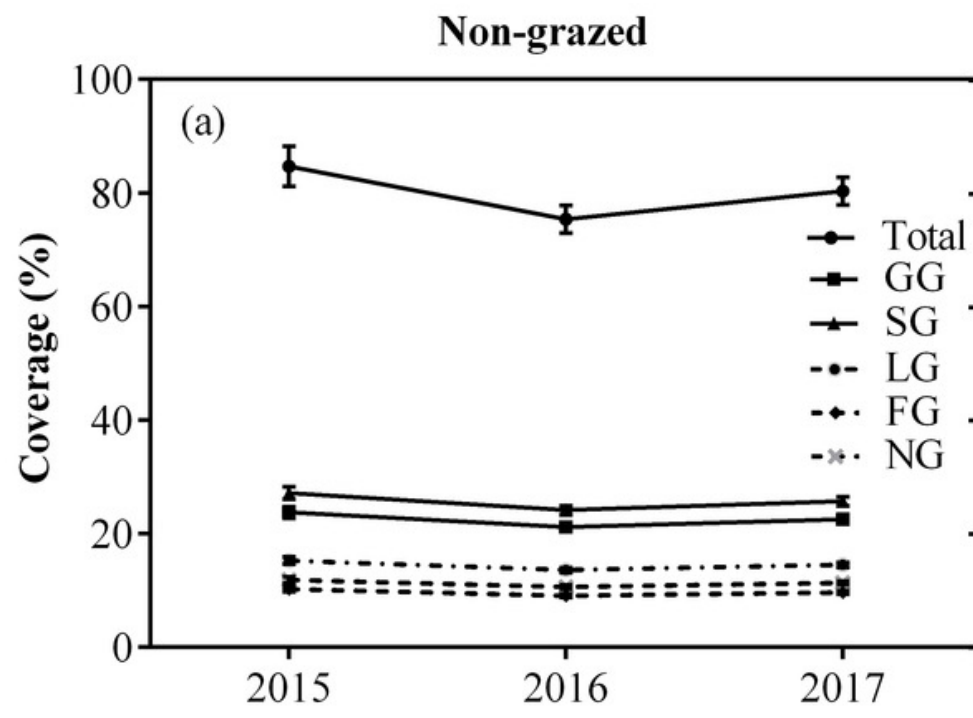

(b)

Grazed

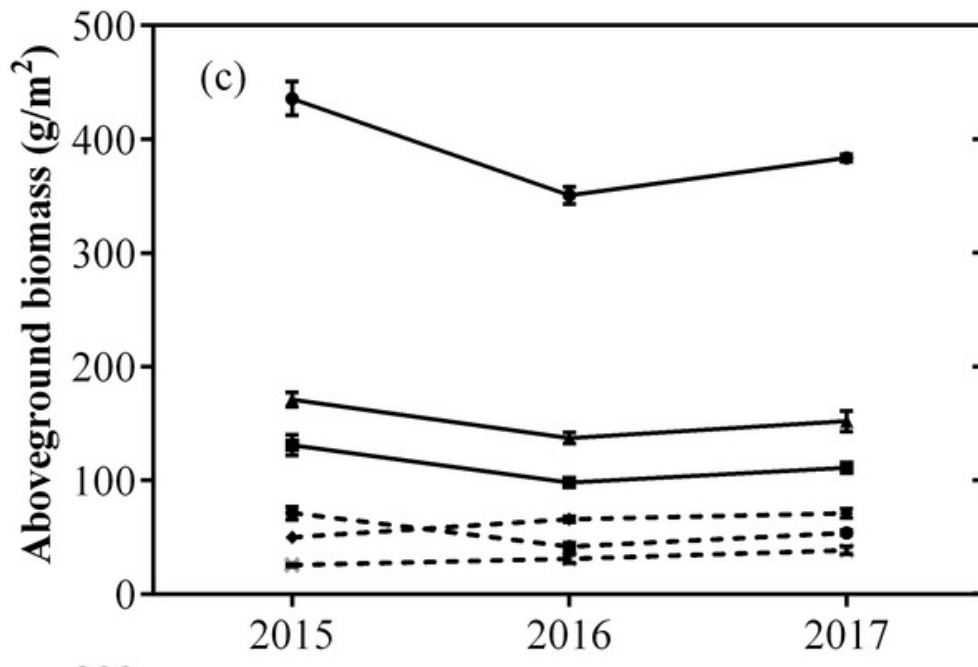

(d)

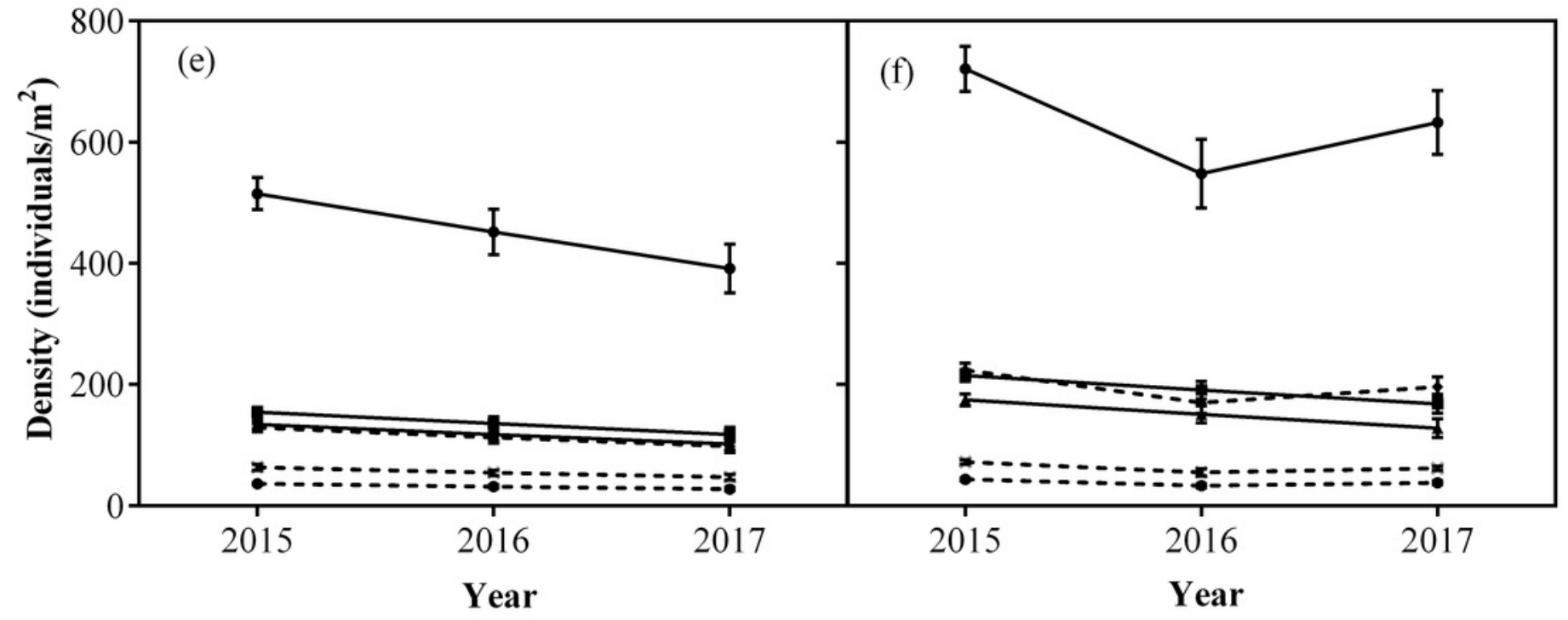

(f)
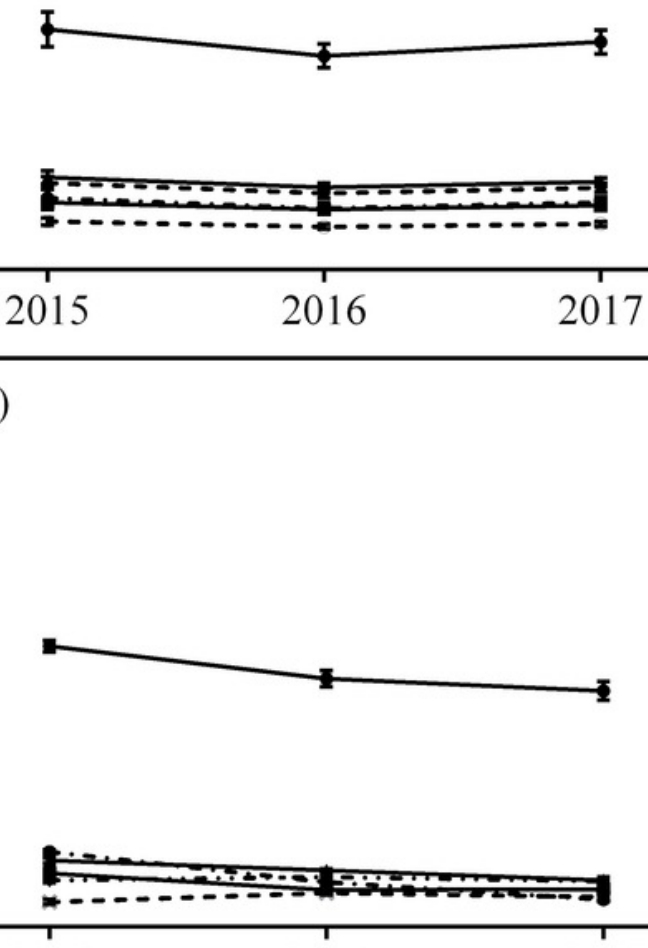

$2015 \quad 2016$

2017 


\section{Figure 5}

Effect of non-grazed and grazed on four edible functional types CP (\%), IVTD (\%), NDF (\%) of alpine meadows between non-grazed and grazed treatment.

The values (Mean \pm SE) are means of 3 years (2015, 2016 and 2017); GG, SG, LG and FG represents grass species type, sedge species type, leguminous species type and forbs species type respectly. The symbols represent signigicant difference between non-grazed and grazed alpine meadow treatemnts, ${ }^{* * * P}<0.001,{ }^{* * P}<0.01,{ }^{*} P<0.05$; ns, no significant difference. 

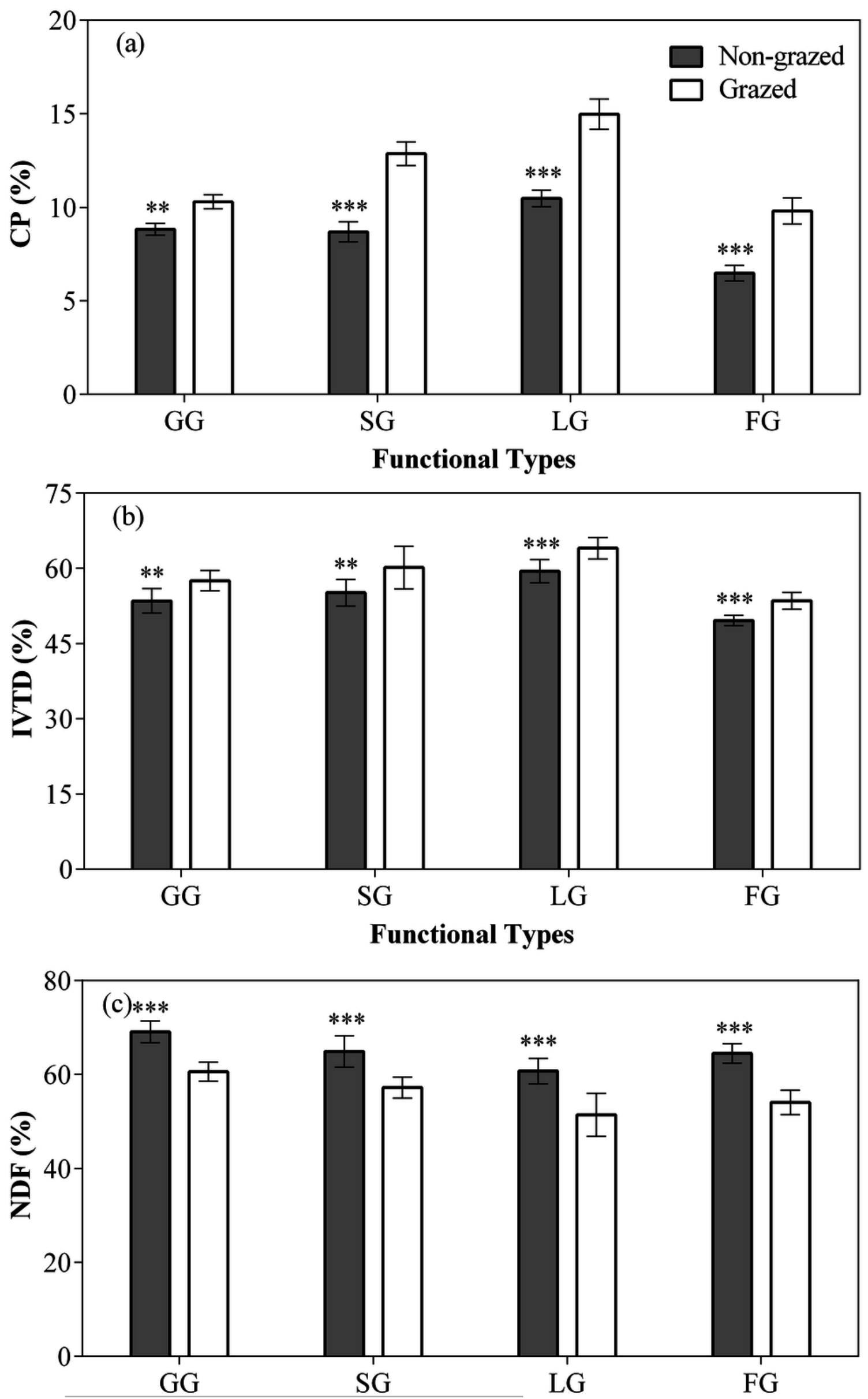


\section{Figure 6}

Changes of CP (\%), IVTD (\%), NDF (\%) for four edible functional types (GG, SG, LG and FG) between non-grazed and grazed alpine meadows.

The values (Mean \pm SE) are means of 3 years (2015, 2016 and 2017); GG, SG, LG and FG represents grass species type, sedge species type, leguminous species type and forbs species type respectively. 


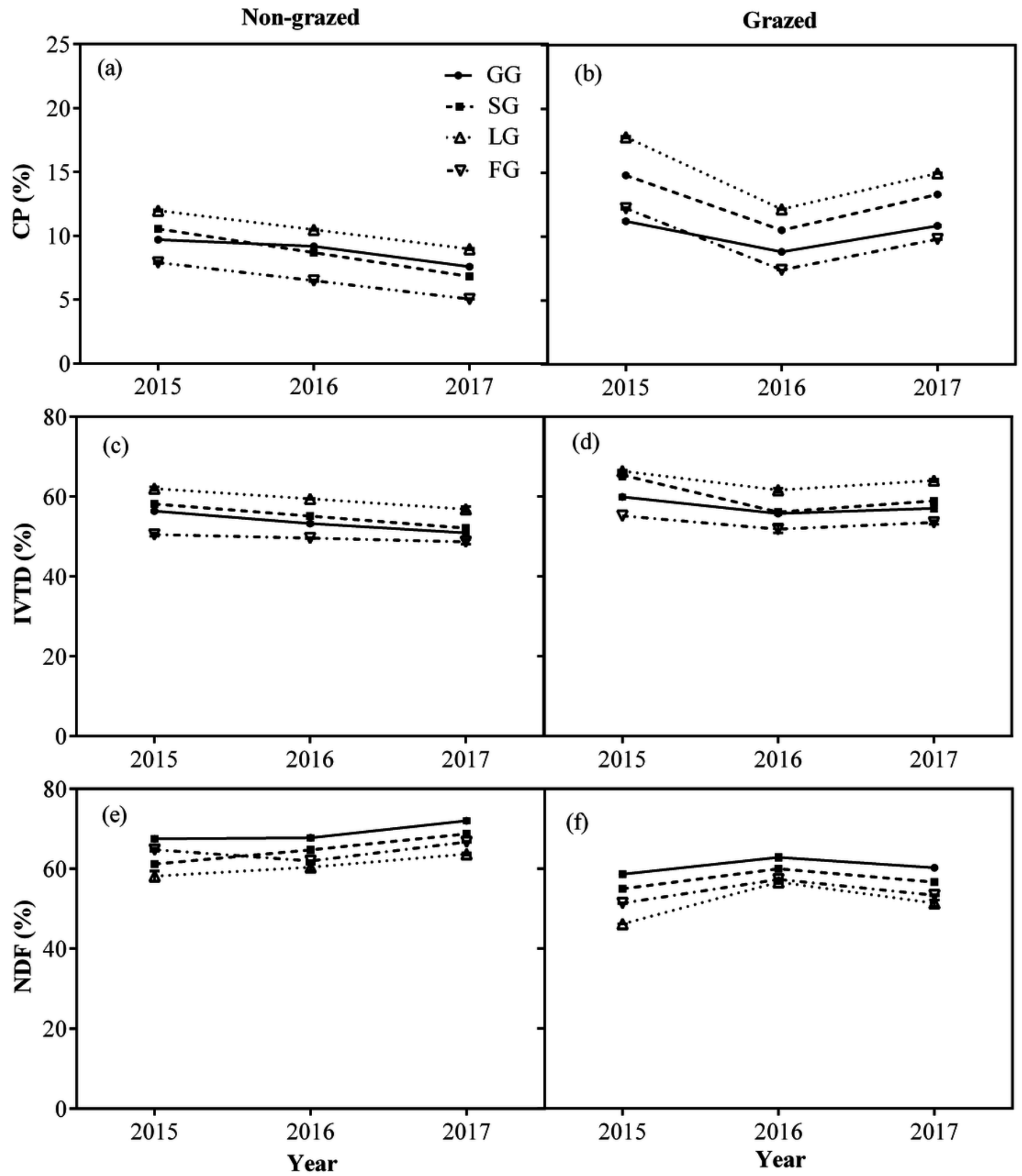




\section{Figure 7}

Effect of non-grazed and grazed on soil properties TN $(\mathrm{g} / \mathrm{kg})$, TP $(\mathrm{g} / \mathrm{kg}), \mathrm{TK}(\mathrm{g} / \mathrm{kg})$, AN $(\mathrm{mg} / \mathrm{kg}), \mathrm{AP}(\mathrm{mg} / \mathrm{kg})$ and AK $(\mathrm{mg} / \mathrm{kg})$ of alpine meadow between non-grazed and grazed treatment in $3(0-10,10-20$ and $20-30 \mathrm{~cm})$ soil depths.

The values (Mean \pm SE) are means of 3 years (2015, 2016 and 2017). The symbols represent signigicant difference between non-grazed and grazed alpine meadow treatemnts, ${ }^{*} * *<0.001,{ }^{* * P} P<0.01, * P<0.05$; ns, no significant difference. 

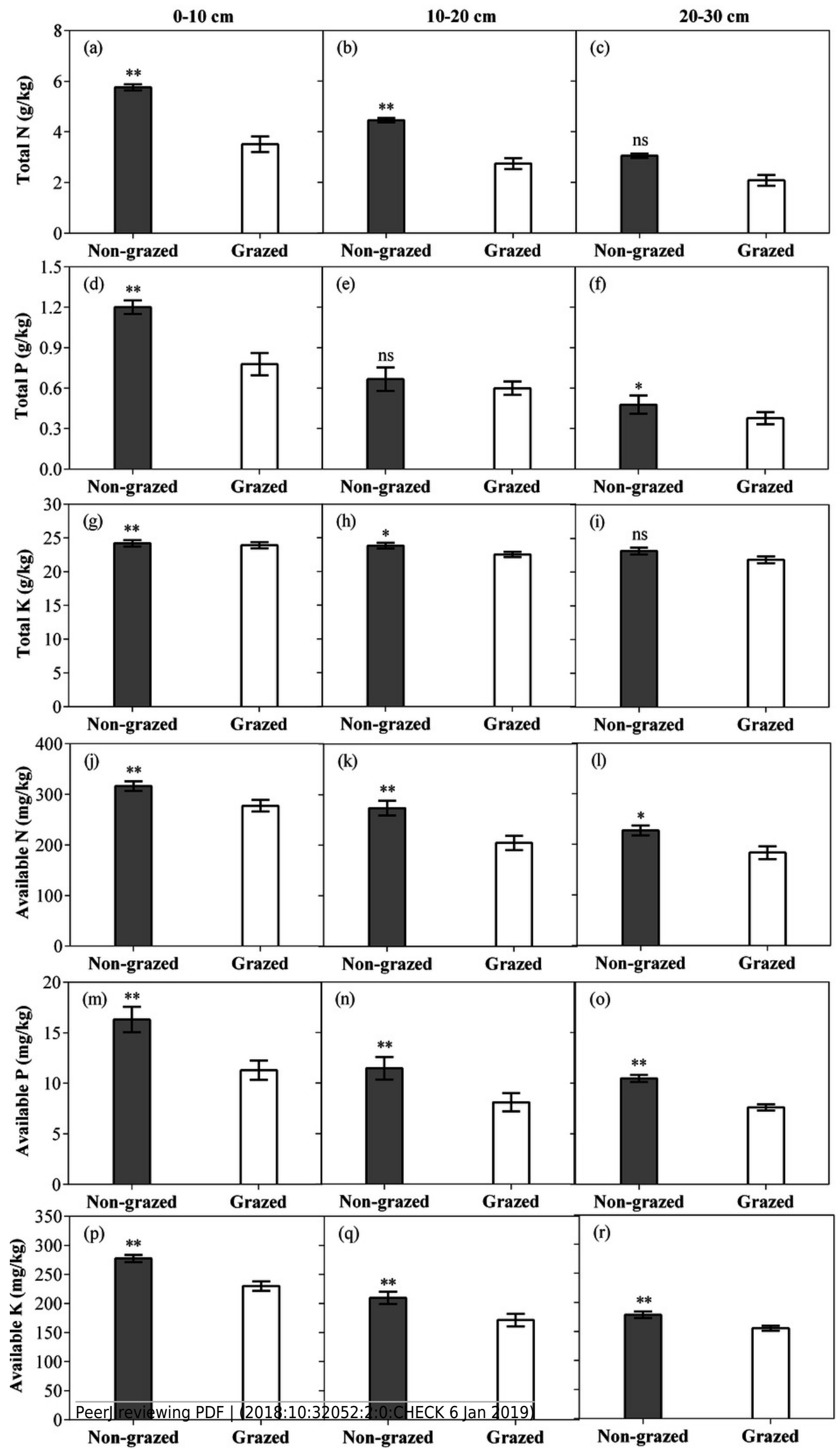
Figure 8

Changes of TN $(\mathrm{g} / \mathrm{kg})$, TP $(\mathrm{g} / \mathrm{kg})$, TK $(\mathrm{g} / \mathrm{kg})$, AN $(\mathrm{mg} / \mathrm{kg}), A P(\mathrm{mg} / \mathrm{kg})$ and AK $(\mathrm{mg} / \mathrm{kg})$ for 3 $(0-10,10-20$ and $20-30 \mathrm{~cm})$ soil depths between non-grazed and grazed alpine meadows.

The values (Mean \pm SE) are means of 3 years (2015, 2016 and 2017). 

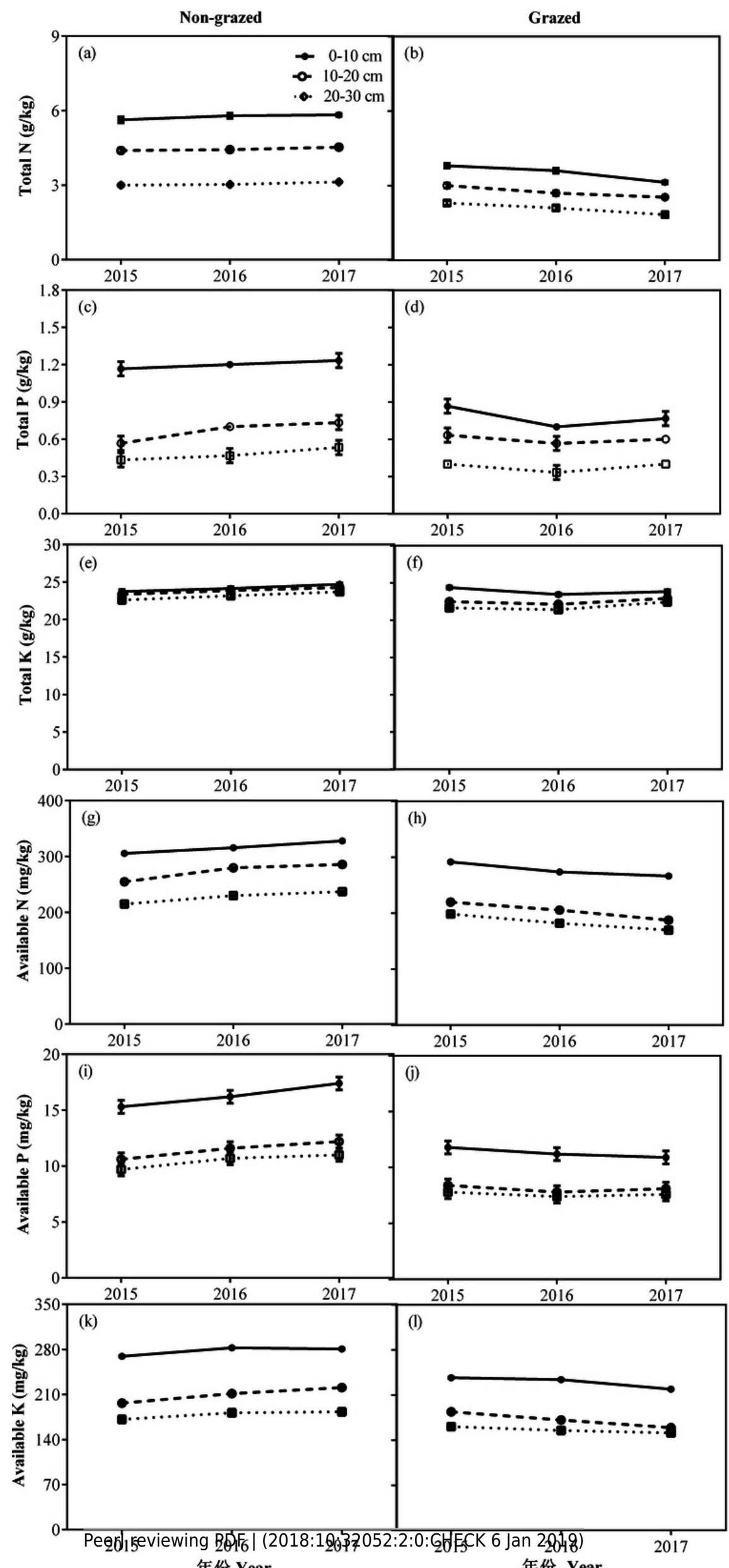


\section{Table $\mathbf{1}$ (on next page)}

The mean aboveground biomass $\left(\mathrm{g} / \mathrm{m}^{2}\right)$ for species present at surveyed quadrats of long-term non-grazed and grazed alpine meadows in 2015, 2016 and 2017.

Note: For life types of species, $\mathrm{P}$ and $\mathrm{A}$ represents perennials and annuals respectly. For edibility, E and I represents edible and inedible respectively. For five functional types, GG, SG, LG, FG and NG represents grass species type, sedge species type, leguminous species type, forbs species type and noxious species type respectly. "_" not present. 
1 Table 1. The mean aboveground biomass $\left(\mathrm{g} / \mathrm{m}^{2}\right)$ for species present at surveyed quadrats of 2 long-term non-grazed and grazed alpine meadows in 2015, 2016 and 2017.

\begin{tabular}{|c|c|c|c|c|c|c|c|c|c|}
\hline \multirow{3}{*}{ Species } & \multirow{3}{*}{$\begin{array}{l}\text { Life } \\
\text { type }\end{array}$} & \multirow{3}{*}{ Edibility } & \multirow{3}{*}{$\begin{array}{c}\text { Functional } \\
\text { types }\end{array}$} & \multicolumn{6}{|c|}{ Aboveground vegetation productivity (g/m²) } \\
\hline & & & & \multicolumn{2}{|c|}{2015} & \multicolumn{2}{|c|}{2016} & \multicolumn{2}{|c|}{2017} \\
\hline & & & & non-grazed & Grazed & non-grazed & Grazed & non-grazed & Grazed \\
\hline Elymus nutans Griseb. & $\mathrm{P}$ & $\mathrm{E}$ & GG & 38.72 & 12.13 & 28.21 & 8.23 & 35.11 & 3.15 \\
\hline B. Sylvaticum (Huds) Beauv & $\mathrm{P}$ & $\mathrm{E}$ & GG & 17.22 & 7.86 & 6.15 & 2.18 & - & 2.44 \\
\hline Roegneria kamoji Ohwi & $\mathrm{P}$ & $\mathrm{E}$ & GG & - & 1.22 & - & 0.52 & - & - \\
\hline Stipa aliena Keng & $\mathrm{P}$ & $\mathrm{E}$ & GG & 20.15 & 5.83 & 17.86 & 7.89 & 26.25 & 9.51 \\
\hline Poa crymophila Keng & $\mathrm{P}$ & $\mathrm{E}$ & GG & 54.90 & 20.05 & 45.99 & 13.51 & 49.86 & 17.86 \\
\hline Kobresia humilis (C. A. Mey. ex & $\mathrm{P}$ & $\mathrm{E}$ & SG & 85.32 & 27.15 & 58.16 & 27.21 & 68.55 & 23.81 \\
\hline \multicolumn{10}{|l|}{ Trautv.) Sergiev } \\
\hline Scirpus triqueter $\mathrm{L}$. & $\mathrm{P}$ & $\mathrm{E}$ & SG & - & 8.06 & - & 6.35 & - & - \\
\hline Carex capillifolia (Decne.) S. R. & $\mathrm{P}$ & $\mathrm{E}$ & SG & 65.72 & 17.05 & 67.30 & 13.50 & 59.38 & 14.58 \\
\hline \multicolumn{10}{|l|}{ Zhang (2015) } \\
\hline Carex melanocephala Turcz. ex Bess. & $\mathrm{P}$ & $\mathrm{E}$ & SG & 20.01 & 6.15 & 11.86 & 2.67 & 24.12 & 2.50 \\
\hline Caragana sinica (Buc'hoz) Rehder & $\mathrm{P}$ & $\mathrm{E}$ & LG & 42.35 & 38.11 & 30.50 & 28.85 & 43.50 & 20.36 \\
\hline Medicago ruthenica var. inschanica & $\mathrm{P}$ & $\mathrm{E}$ & LG & 26.50 & 24.23 & 6.98 & 6.86 & 10.42 & 3.05 \\
\hline Gueldenstaedtia verna (Georgi) Boriss & $\mathrm{P}$ & $\mathrm{E}$ & LG & - & 2.48 & - & 1.21 & - & - \\
\hline Medicago ruthenica (L.) Trautv. & $\mathrm{P}$ & $\mathrm{E}$ & LG & 2.45 & 1.24 & 4.20 & 2.21 & - & 0.45 \\
\hline Polygonum viviparum $\mathrm{L}$. & $\mathrm{P}$ & $\mathrm{E}$ & FG & 12.30 & 9.51 & 21.22 & 18.77 & 20.56 & 20.30 \\
\hline Polygonum macrophyllum D. Don & $\mathrm{P}$ & $\mathrm{E}$ & FG & 7.45 & 6.80 & 9.70 & 5.06 & 15.83 & 13.05 \\
\hline Saussurea japonica (Thunb.) DC. & $P$ & $\mathrm{E}$ & FG & 4.50 & 2.55 & - & 3.45 & - & - \\
\hline Potentilla fruticosa $\mathrm{L}$. & $P$ & $\mathrm{E}$ & FG & 17.02 & 12.90 & 24.11 & 15.01 & 34.50 & 7.01 \\
\hline
\end{tabular}




\begin{tabular}{|c|c|c|c|c|c|c|c|c|c|}
\hline Salix oritrepha Schneid. & $\mathrm{P}$ & $\mathrm{E}$ & FG & 5.51 & 4.15 & 7.51 & 4.92 & - & 0.21 \\
\hline Heteropappus altaicus & A & $\mathrm{E}$ & FG & - & 8.05 & - & - & - & - \\
\hline \multicolumn{10}{|l|}{ Novopokr } \\
\hline Thalictrum aquilegifolium & $\mathrm{P}$ & $\mathrm{I}$ & NG & 3.72 & 3.26 & 2.89 & 2.45 & - & 3.15 \\
\hline Taraxacum mongolicum Hand.-Mazz. & $\mathrm{P}$ & $\mathrm{I}$ & NG & - & 1.25 & - & 1.88 & - & 2.21 \\
\hline Leontopodium alpinum & $\mathrm{P}$ & $\mathrm{I}$ & NG & 2.58 & 1.98 & - & 1.56 & 2.65 & - \\
\hline Potentilla bifurca Linn. & $\mathrm{P}$ & $\mathrm{I}$ & NG & 3.10 & 2.77 & 4.58 & 3.51 & 3.82 & 4.68 \\
\hline Stellera chamaejasme L. & $\mathrm{P}$ & I & NG & 1.32 & 2.12 & 3.66 & 2.66 & 2.52 & 6.85 \\
\hline Oxytropis ochrocephala & $\mathrm{P}$ & I & NG & 4.58 & 3.54 & - & - & 1.52 & - \\
\hline Geranium wilfordii Maxim. & $\mathrm{P}$ & I & NG & - & - & - & 0.85 & - & - \\
\hline Oxytropis kansuensis & $\mathrm{P}$ & I & NG & 3.85 & 1.99 & 7.89 & 6.08 & 5.77 & 5.27 \\
\hline Gentiana scabra Bunge & A & I & NG & 0.65 & 0.81 & 4.56 & 6.50 & 6.25 & 2.80 \\
\hline Pedicularis ikomai Sasaki & $\mathrm{P}$ & I & NG & 1.21 & 1.13 & - & - & - & 2.11 \\
\hline Gentianopsis paludosa & A & $\mathrm{I}$ & NG & - & 0.85 & - & 1.51 & 1.86 & 2.98 \\
\hline Polygonum sibiricum Laxm. & $\mathrm{P}$ & I & NG & - & 1.67 & - & 2.21 & - & - \\
\hline Plantago asiatica $\mathrm{L}$. & $\mathrm{P}$ & $\mathrm{I}$ & NG & 0.41 & 2.21 & - & - & - & 2.25 \\
\hline Artemisia hedinii Ostenf. et Pauls. & A & I & NG & - & 1.15 & 3.64 & - & - & 3.66 \\
\hline Gentiana macrophylla & $\mathrm{P}$ & I & NG & 0.35 & 0.68 & 1.68 & 1.61 & 1.89 & 1.64 \\
\hline Rheum pumilum Maxim. & $\mathrm{P}$ & I & NG & - & & 0.84 & 0.26 & - & 0.21 \\
\hline
\end{tabular}

3 Note: For life types of species, $\mathrm{P}$ and A represents perennials and annuals respectly. For edibility, E and I 4 represents edible and inedible respectively. For five functional types, GG, SG, LG, FG and NG represents 5 grass species type, sedge species type, leguminous species type, forbs species type and noxious species type 6 respectly. "-" not present. 


\section{Table 2 (on next page)}

The effects of years (2015, 2016 and 2017), non-grazed (comparied with grazed) and interaction between non-grazed and year Coverage ( $a, \%)$, Aboveground biomass (b), Density (c) for total vegetation and five functional types.

GG, SG, LG, FG and NG represents grass species type, sedge species type, leguminous species type, forbs species type and noxious species type respectly. 
1 Table 2. The effects of years (2015, 2016 and 2017), non-grazed (comparied with grazed) 2 and interaction between non-grazed and year Coverage (a, \%), Aboveground biomass (b), 3 Density (c) for total vegetation and five functional types, GG, SG, LG, FG and NG 4 represents grass species type, sedge species type, leguminous species type, forbs species type 5 and noxious species type respectly.

\begin{tabular}{|c|c|c|c|c|c|c|}
\hline \multirow{2}{*}{ Functional types } & \multirow{2}{*}{ Items } & \multicolumn{5}{|c|}{ P-values of variables } \\
\hline & & Non-grazed & Plots & Year & Non-grazed $\times$ Year & Year $\times$ Plots \\
\hline & Coverage & 0.001 & 0.725 & 0.014 & 0.925 & 0.915 \\
\hline \multirow[t]{3}{*}{ Total } & Plant density & 0.006 & 0.684 & 0.027 & 0.849 & 0.955 \\
\hline & Aboveground biomass & 0.012 & 0.551 & 0.326 & 0.001 & 0.924 \\
\hline & Coverage & 0.001 & 0.594 & 0.106 & 0.582 & 0.842 \\
\hline \multirow[t]{3}{*}{ GG } & Plant density & 0.003 & 0.421 & 0.013 & 0.924 & 0.882 \\
\hline & Aboveground biomass & 0.005 & 0.421 & 0.126 & 0.209 & 0.855 \\
\hline & Coverage & 0.001 & 0.861 & 0.059 & 0.729 & 0.769 \\
\hline \multirow[t]{3}{*}{ SG } & Plant density & 0.015 & 0.348 & 0.033 & 0.820 & 0.687 \\
\hline & Aboveground biomass & 0.006 & 0.689 & 0.272 & 0.048 & 0.910 \\
\hline & Coverage & 0.000 & 0.722 & 0.004 & 0.979 & 0.815 \\
\hline \multirow[t]{3}{*}{ LG } & Plant density & 0.006 & 0.429 & 0.008 & 0.952 & 0.958 \\
\hline & Aboveground biomass & 0.288 & 0.596 & 0.170 & 0.004 & 0.815 \\
\hline & Coverage & 0.004 & 0.915 & 0.087 & 0.596 & 0.845 \\
\hline \multirow[t]{2}{*}{ FG } & Plant density & 0.006 & 0.582 & 0.068 & 0.672 & 0.975 \\
\hline & Aboveground biomass & 0.080 & 0.662 & 0.470 & 0.006 & 0.933 \\
\hline NG & Coverage & 0.001 & 0.824 & 0.023 & 0.888 & 0.955 \\
\hline
\end{tabular}




\begin{tabular}{cccccc} 
Plant density & 0.002 & 0.253 & 0.002 & 0.989 & 0.726 \\
& & & & & 0.979 \\
Aboveground biomass & 0.231 & 0.754 & 0.288 & 0.110 & 0.979 \\
\hline
\end{tabular}

6 


\section{Table 3(on next page)}

The effects of years (2015, 2016 and 2017), non-grazed (comparied with grazed) and interaction between non-grazed and year on CP (\%), IVTD (\%) and NDF (\%) for four edible functional types.

GG, SG, LG and FG represents grass species type, sedge species type, leguminous species type and forbs species type respectly. 
1 Table 3. The effects of years (2015, 2016 and 2017), non-grazed (comparied with grazed) 2 and interaction between non-grazed and year on CP (\%), IVTD (\%) and NDF (\%) for four 3 edible functional types, GG, SG, LG and FG represents grass species type, sedge species 4 type, leguminous species type and forbs species type respectly.

\begin{tabular}{|c|c|c|c|c|c|c|}
\hline \multirow{2}{*}{ Functional types } & \multirow{2}{*}{ Items } & \multicolumn{5}{|c|}{ P-values of variables } \\
\hline & & Non-grazed & Plots & Year & Non-grazed $\times$ Year & Year $\times$ Plots \\
\hline & $\mathrm{CP}$ & 0.007 & 0.105 & 0.008 & 0.019 & 0.595 \\
\hline \multirow[t]{3}{*}{ GG } & IVTD & 0.009 & 0.322 & 0.019 & 0.328 & 0.911 \\
\hline & $\mathrm{NDF}$ & 0.004 & 0.122 & 0.035 & 0.279 & 0.859 \\
\hline & $\mathrm{CP}$ & 0.005 & 0.230 & 0.015 & 0.000 & 0.871 \\
\hline \multirow[t]{3}{*}{ SG } & IVTD & 0.047 & 0.612 & 0.060 & 0.015 & 0.822 \\
\hline & $\mathrm{NDF}$ & 0.010 & 0.326 & 0.041 & 0.007 & 0.820 \\
\hline & $\mathrm{CP}$ & 0.027 & 0.332 & 0.083 & 0.000 & 0.671 \\
\hline \multirow[t]{3}{*}{ LG } & IVTD & 0.001 & 0.235 & 0.001 & 0.904 & 0.902 \\
\hline & $\mathrm{NDF}$ & 0.023 & 0.455 & 0.088 & 0.015 & 0.952 \\
\hline & $\mathrm{CP}$ & 0.026 & 0.258 & 0.057 & 0.000 & 0.588 \\
\hline \multirow[t]{2}{*}{ FG } & IVTD & 0.012 & 0.509 & 0.078 & 0.386 & 0.740 \\
\hline & NDF & 0.020 & 0.311 & 0.227 & 0.000 & 0.574 \\
\hline
\end{tabular}


Table 4 (on next page)

The effects of years (2015, 2016 and 2017), non-grazed (comparied with grazed) and interaction between non-grazed and year on TN, TP, TK, AN, AP and AK for $3(0-10,10-$ 20 and $20-30 \mathrm{~cm}$ ) soil depths. 
1 Table 4. The effects of years (2015, 2016 and 2017), non-grazed (comparied with grazed) 2 and interaction between non-grazed and year on TN, TP, TK, AN, AP and AK for 3 (0-10, $3 \quad 10-20$ and $20-30 \mathrm{~cm}$ ) soil depths.

\begin{tabular}{|c|c|c|c|c|c|c|}
\hline \multirow{2}{*}{ Soil properties } & \multirow{2}{*}{ Soil depth (cm) } & \multicolumn{5}{|c|}{ P-values of variables } \\
\hline & & Non-grazed & Plots & Year & Non-grazed $\times$ Year & Year $\times$ Plots \\
\hline \multirow{4}{*}{ Total N (g/kg) } & $0-10$ & 0.004 & 0.364 & 0.247 & 0.002 & 0.856 \\
\hline & $10-20$ & 0.003 & 0.662 & 0.252 & 0.006 & 0.854 \\
\hline & $20-30$ & 0.018 & 0.522 & 0.419 & 0.001 & 0.815 \\
\hline & $0-10$ & 0.006 & 0.357 & 0.258 & 0.020 & 0.911 \\
\hline \multirow[t]{3}{*}{ Total P (g/kg) } & $10-20$ & 0.151 & 0.647 & 0.241 & 0.019 & 0.847 \\
\hline & $20-30$ & 0.030 & 0.522 & 0.291 & 0.232 & 0.996 \\
\hline & $0-10$ & 0.007 & 0.536 & 0.002 & 0.948 & 0.995 \\
\hline \multirow[t]{3}{*}{ Total K (g/kg) } & $10-20$ & 0.042 & 0.541 & 0.285 & 0.011 & 0.866 \\
\hline & $20-30$ & 0.072 & 0.611 & 0.377 & 0.001 & 0.851 \\
\hline & $0-10$ & 0.002 & 0.233 & 0.015 & 0.001 & 0.634 \\
\hline \multirow[t]{3}{*}{ Available N (mg/kg) } & $10-20$ & 0.001 & 0.416 & 0.018 & 0.000 & 0.513 \\
\hline & $20-30$ & 0.023 & 0.411 & 0.205 & 0.000 & 0.715 \\
\hline & $0-10$ & 0.005 & 0.366 & 0.128 & 0.595 & 0.978 \\
\hline \multirow[t]{3}{*}{ Available P (mg/kg) } & $10-20$ & 0.017 & 0.622 & 0.363 & 0.438 & 0.710 \\
\hline & $20-30$ & 0.020 & 0.378 & 0.494 & 0.480 & 0.814 \\
\hline & $0-10$ & 0.001 & 0.255 & 0.019 & 0.006 & 0.456 \\
\hline \multicolumn{7}{|l|}{ Available K (mg/kg) } \\
\hline & $10-20$ & 0.001 & 0.425 & 0.005 & 0.037 & 0.642 \\
\hline
\end{tabular}


